\title{
Synthesis and Evaluation of Hydrogen Peroxide Sensitive Prodrugs of Methotrexate and Aminopterin for the Treatment of Rheumatoid Arthritis
}

Peiró Cadahía, Jorge; Bondebjerg, Jon; Hansen, Christian A.; Previtali, Viola; Hansen, Anders E.; Andresen, Thomas L.; Clausen, Mads Hartvig

Published in:

Journal of Medicinal Chemistry

Link to article, DOI:

10.1021/acs.jmedchem.7b01775

Publication date:

2018

Document Version

Peer reviewed version

Link back to DTU Orbit

Citation (APA):

Peiró Cadahía, J., Bondebjerg, J., Hansen, C. A., Previtali, V., Hansen, A. E., Andresen, T. L., \& Clausen, M. H. (2018). Synthesis and Evaluation of Hydrogen Peroxide Sensitive Prodrugs of Methotrexate and Aminopterin for the Treatment of Rheumatoid Arthritis. Journal of Medicinal Chemistry, 61(8), 3503-3515.

https://doi.org/10.1021/acs.jmedchem.7b01775

\section{General rights}

Copyright and moral rights for the publications made accessible in the public portal are retained by the authors and/or other copyright owners and it is a condition of accessing publications that users recognise and abide by the legal requirements associated with these rights.

- Users may download and print one copy of any publication from the public portal for the purpose of private study or research.

- You may not further distribute the material or use it for any profit-making activity or commercial gain

- You may freely distribute the URL identifying the publication in the public portal 


\section{Synthesis and Evaluation of Hydrogen Peroxide}

\section{Sensitive Prodrugs of Methotrexate and Aminopterin}

\section{for the Treatment of Rheumatoid Arthritis}

Jorge Peiró Cadahía ${ }^{\dagger}$, Jon Bondebjerg ${ }^{\S}$, Christian A. Hansen ${ }^{\#}$, Viola Previtali ${ }^{\dagger}$, Anders E. Hansen $^{\ddagger}$, Thomas L. Andresen ${ }^{\ddagger}$, and Mads H. Clausen ${ }^{\dagger, *}$

${ }^{\dagger}$ Center for Nanomedicine \& Theranostics, Department of Chemistry, Technical University of Denmark, Kemitorvet 207, DK-2800 Kongens Lyngby, Denmark. ${ }^{\S}$ MC2 Therapeutics, Ager Alle 24-26, 2970 Hørsholm, Denmark, " Capdelta Group Aps, C/O Kavsbjerglund 30, DK-2740 Skovlunde, Denmark, ${ }^{\ddagger}$ Center for Nanomedicine \& Theranostics, Department of Micro- and Nanotechnology, Technical University of Denmark, Ørsteds Plads, Building 345, DK-2800 Kongens Lyngby, Denmark. 
ABSTRACT. A series of novel hydrogen peroxide sensitive prodrugs of methotrexate (MTX) and aminopterin (AMT) were synthesized and evaluated for therapeutic efficacy in mice with collagen induced arthritis (CIA) as a model of chronic rheumatoid arthritis (RA). The prodrug strategy selected is based on ROS-labile 4-methylphenylboronic acid promoieties linked to the drugs via a carbamate linkage or a direct $\mathrm{C}-\mathrm{N}$ bond. Activation under patho-physiological concentrations of $\mathrm{H}_{2} \mathrm{O}_{2}$ proved to be effective and prodrug candidates were selected in agreement with relevant in vitro physicochemical and pharmacokinetic assays. Selected candidates showed moderate to good solubility, high chemical and enzymatic stability, and therapeutic efficacy comparable to the parent drugs in the CIA model. Importantly, the prodrugs displayed the expected safer toxicity profile and increased therapeutic window compared to MTX and AMT while maintaining a comparable therapeutic efficacy, which is highly encouraging for future use in RA patients.

KEYWORDS: aminopterin, collagen-induced arthritis, hydrogen peroxide, methotrexate, phenylboronic acid, prodrug, rheumatoid arthritis. 


\section{INTRODUCTION}

Rheumatoid arthritis (RA) is an autoimmune disease characterized by chronic destructive synovitis and is associated with progressive disability, systemic difficulties, premature death, and socioeconomic costs. ${ }^{1}$ The cause of RA remains unknown and currently no cure for the disease exists. Several studies have estimated the prevalence of RA to range between $0.5 \%$ to $1 \%$ of the adult population in developed countries, with a 3 to 1 female to male ratio. ${ }^{2}$

Aminopterin (1, AMT, Figure 1), an anti-folate drug initially developed for treatment of leukemia, was tested for RA treatment in $1951 . .^{3,4}$ Complex manufacturing, ${ }^{5}$ unpredictable toxicities, ${ }^{6-9}$ and low therapeutic index ${ }^{8,10}$ led scientist to develop methotrexate (2, MTX, Figure 1), as an alternative antifolate for cancer therapy which later showed anti-arthritic properties as a disease modifying anti-rheumatic drug (DMARD). In 1988, low-dose MTX (LD-MTX, $<30 \mathrm{mg}$ in weekly pulses) was approved by the FDA for the treatment of RA and has remained the standard of care since. ${ }^{11,12}$ Although efficacious, the mechanisms that govern the anti-inflammatory and immunosuppressive effects of MTX in rheumatic diseases are still not completely understood. ${ }^{13}$ Furthermore, the population of patients that will be responsive to an MTX regiment cannot be reliably predicted before initiating treatment. ${ }^{14}$ Adverse effects and low efficacy of LD-MTX in RA are the predominant reasons for discontinuation of treatment. Side effects are usually mild, self-limiting, and/or preventable, but a subset of patients suffers from severe side-effects. Toxicities including anemia, neutropenia, stomatitis, oral ulcers, lethargy, fatigue, nodulosis, hepatic and pulmonary fibrosis, as well as renal insufficiency are associated to this drug. ${ }^{15-18}$ Additionally, progressive drug tolerance of disease, high patient variability, and pharmacokinetic inadequacies of LD-MTX suggest the need of more efficient and safer RA therapies. 


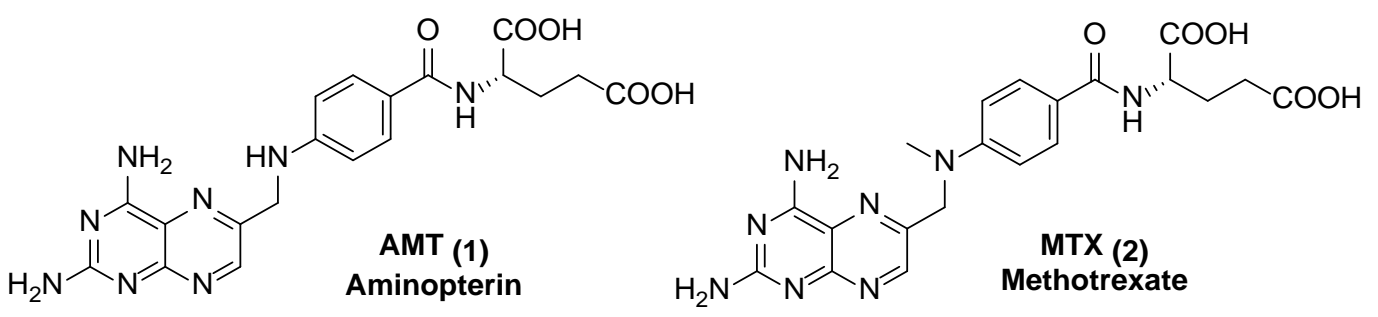

Figure 1. Chemical structure of aminopterin (AMT, 1) and methotrexate (MTX, 2)

Prodrugs are chemically modified drugs that have either no or greatly decreased activity compared to the parent drug. Upon administration, prodrugs are activated in the body through chemical and/or enzymatic transformation into the pharmaceutically active moiety. ${ }^{19}$ Approximately $20 \%$ of drugs approved since 2000 are prodrugs, ${ }^{20}$ mostly designed to minimize and/or overcome unacceptable absorption, distribution, metabolism, excretion, and toxicity (ADMET) properties of the native drug. ${ }^{21}$ Several prodrugs, drug conjugates, and drug delivery systems for methotrexate have been reported in the literature but none of them have been approved for clinical use yet. ${ }^{22-33}$

Reactive oxygen species (ROS), like $\mathrm{H}_{2} \mathrm{O}_{2}, \mathrm{HO}^{\bullet}, \mathrm{O}_{2}{ }^{-}$, produced by phagocytes and neutrophils, ${ }^{34}$ have important physiological roles in priming the immune system. ${ }^{35,36}$ Increasing evidence from different studies supports the relation between oxidative stress and the pathogenesis of inflammation and rheumatoid arthritis. ${ }^{37,38}$ In RA, oxidative stress has been described as an important mechanism in the pathogenesis of destructive proliferative synovitis. Under pathological inflammatory conditions, the extracellular concentration of $\mathrm{H}_{2} \mathrm{O}_{2}$, the most stable ROS, has been determined to be up to a 100-fold higher compared to healthy tissue, reaching concentrations as high as $1.0 \mathrm{mM}^{39-44}$ The presence of increased concentrations of $\mathrm{H}_{2} \mathrm{O}_{2}$ in the inflammatory environment can serve as the stimulus for prodrug activation in site-selective drug delivery 
systems. Phenylboronic acids and esters, ${ }^{45-48}$ phenylsulfonate esters, ${ }^{49}$ thiazolidinones, ${ }^{44} \mathrm{~N}-(2,5-$ dihydroxyphenyl)acetamides, ${ }^{50}$ and $\alpha$-boryl ethers, carbonates, and acetals ${ }^{51}$ have been reported as useful structural motifs for hydrogen peroxide activatable prodrugs and imaging, but studies have mainly focused on their applications in oncology.

Here we propose a new approach to RA therapy based on the use of phenylboronic acidcontaining prodrugs that are inactive until activated locally in the inflammatory tissue. This mechanism secures that the biological activity is limited to regions of inflammation to facilitate a safer toxicity profile compared to AMT and MTX, and a more effective treatment due to the expected localization and accumulation in the target tissue. We have designed and synthesized a series of MTX and AMT prodrugs that are activated by disease- and tissue-specific factors like $\mathrm{H}_{2} \mathrm{O}_{2}$. Their physicochemical, pharmacokinetic, and drug-like properties have been evaluated in in vitro assays. Additionally, their in vivo efficacy and preliminary toxicity in the murine collageninduced arthritis model (CIA) was assessed.

\section{RESULTS AND DISCUSSION}

Synthesis of prodrugs. The pinacolates $\mathbf{4 b}$ and $\mathbf{4 c}$ were synthesized from the corresponding 4-hydroxymethylphenyl boronic acids 3b and 3c via condensation with pinacol (Scheme 1). Subsequently, the chloroformates $\mathbf{5 a - c}$ were achieved by reaction of $\mathbf{3 a - c}$ with phosgene. In parallel, the MTX core structure was synthesized starting with bromination of 2,4-diamino-6(hydroxymethyl)pteridine hydrochloride $(6 \cdot \mathrm{HCl})$ and alkylation of 4-methylaminobenzoic acid to form the pteoric acid 7, following the procedure described by Kralovej et al. ${ }^{52}$ Amide coupling of $\mathbf{7}$ with dimethylglutamate hydrochloride $\mathbf{9} \cdot \mathrm{HCl}$, synthesized from glutamic acid $\mathbf{8}$, provided methotrexate dimethylester $\mathbf{1 0}$. Finally, coupling between $\mathbf{1 0}$ and $\mathbf{5 a - c}$ formed the desired prodrugs 
11-13 after hydrolysis of the pinacolate with $\mathrm{HCl}$ in a mixture of $\mathrm{H}_{2} \mathrm{O} / \mathrm{MeCN}$. The use of DMAP in the coupling step was crucial for the progression of the reaction. Compounds 11-13 represent a set of MTX prodrugs in which the promoiety is linked to MTX via a carbamate linkage. The promoiety contains different ortho-substituents $(\mathrm{H}, \mathrm{F}$ or $\mathrm{Me})$ in order to investigate the effect of modifying the steric and electronic environment around the boronic acid on reactivity towards $\mathrm{H}_{2} \mathrm{O}_{2}$. Furthermore, the carboxylic acids of MTX were also masked as methyl esters.

Scheme 1. Synthesis of MTX prodrugs 11-13<smiles>[R]c1cc(CO)ccc1B(O)O</smiles>

3a, $\mathrm{R}=\mathrm{H}$

3b, $\mathrm{R}=\mathrm{CH}_{3}$

3c, $R=F$

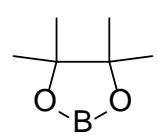<smiles>[R]c1cc(CO)ccc1[Hg]C</smiles>

$4 a^{-} \mathrm{c}$

b

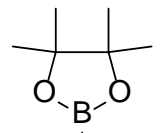<smiles>[R]c1cc(COC(=O)Cl)ccc1C</smiles>

$5 \mathrm{a}^{-} \mathrm{C}$<smiles></smiles><smiles>[R]c1cc(COC(=O)Nc2nc(N)nc3ncc(CN(C)c4ccc(C(=O)N[C@@H](CCC(=O)OC)C(=O)OC)cc4)nc23)ccc1B(O)O</smiles>

${ }^{a}$ Reagents and conditions: (a) pinacol, THF, reflux, $16 \mathrm{~h}$ (>94\%). (b) $\mathrm{COCl}_{2}$ (20\% in toluene), dioxane, $21{ }^{\circ} \mathrm{C}, 20 \mathrm{~h}$ (>95\%). (c) $\mathrm{NaOH}, \mathrm{H}_{2} \mathrm{O}$. (d) $\mathrm{PPh}_{3} \mathrm{Br}_{2}, \mathrm{DMA}, 21{ }^{\circ} \mathrm{C}, 20 \mathrm{~h}$, then 4-methylaminobenzoic acid, DIPEA, 3 days (77\%). (e) PyBOP, Et $3 \mathrm{~N}, \mathrm{DMF}, 2{ }^{\circ} \mathrm{C}, 30 \mathrm{~min}$, then 
9. $\mathrm{HCl}(86 \%)$. (f) $\mathrm{MeOH}, \mathrm{SOCl}_{2}, 21{ }^{\circ} \mathrm{C}$, 4 days (>95\%). (g) 5a-c, DIPEA, DMAP, $\mathrm{CH}_{2} \mathrm{Cl}_{2}, 21{ }^{\circ} \mathrm{C}$, 5 h. (h) $\mathrm{HCl}$ in $\mathrm{H}_{2} \mathrm{O} / \mathrm{MeCN}, 21^{\circ} \mathrm{C}$, 16 h (27-32\%).

Efforts aiming for hydrolysis of the methyl esters in 11-13 using standard conditions based on alkaline hydrolysis with $\mathrm{NaOH}^{53}$ or $\mathrm{LiOH},{ }^{54} \mathrm{LiI}$ in pyridine, ${ }^{55}$ or enzymatic hydrolysis using a polymer supported lipase from Candida antarctica ${ }^{56}$ were unsuccessful. Therefore a new synthetic strategy was proposed (see Scheme 2).

Starting from MTX, the synthesis of the corresponding PMB protected intermediate $\mathbf{1 4}$ was achieved. Following the same procedure described for the synthesis of 11-13, coupling between 5a and 14 afforded 15, which was hydrolyzed to form the corresponding boronic acid 16. Lastly, PMB deprotection under acidic conditions afforded the prodrug 17.

Scheme 2. Synthesis of MTX prodrug $17^{\mathrm{a}}$<smiles>[R]OC(=O)CC[C@H](NC(=O)c1ccc(N(C)Cc2cnc3nc(N)nc(N)c3n2)cc1)C(=O)O[R]</smiles><smiles>CC1(C)OBOC1(C)C</smiles><smiles>CN(Cc1cnc2nc(N)nc(NC(=O)OCc3ccc(B(O)O)cc3)c2n1)c1ccc(C(=O)N[C@@H](CCC(=O)O)C(=O)O)cc1</smiles><smiles>CCCCOC(=O)CC[C@H](NC(=O)c1ccc(N(C)Cc2cnc3nc(N)nc(NC(=O)OCc4ccc(O)cc4)c3n2)cc1)C(=O)OCCC</smiles><smiles>CCCCCC(=O)OCCC[C@H](NC(=O)c1ccc(N(C)Cc2cnc3nc(N)nc(NC(=O)OCc4ccc(B(O)O)cc4)c3n2)cc1)C(=O)OCC</smiles> 
aReagents and conditions: (a) PMBCl, 1,1,3,3-tetramethylguanidine, $\mathrm{CH}_{2} \mathrm{Cl}_{2}, 21{ }^{\circ} \mathrm{C}, 16 \mathrm{~h} \mathrm{(35 \% ).}$ (b) 5a, DIPEA, DMAP, $\mathrm{CH}_{2} \mathrm{Cl}_{2}, 21^{\circ} \mathrm{C}, 5 \mathrm{~h}$ (73\%). (c) $\mathrm{HCl}$ in $\mathrm{H}_{2} \mathrm{O} / \mathrm{MeCN}, 2{ }^{\circ} \mathrm{C}, 20 \mathrm{~h}$ (31\%). (d) $5 \%$ TFA in $\mathrm{CH}_{2} \mathrm{Cl}_{2}, 21^{\circ} \mathrm{C}, 30 \mathrm{~min}(54 \%)$.

Cbz protection of 4-aminobenzoic acid (18) formed 19 and two-step coupling with $\mathbf{9} \cdot \mathrm{HCl}$ produced 20. Hydrogenolysis of $\mathbf{2 0}$ afforded $\mathbf{2 1}$ in high yields, which was subjected to reductive alkylation with 4-formylphenylboronic acid to give 22. Alkylation of 22 with 6-(bromomethyl)2,4-pteridinediamine hydrobromide $(\mathbf{2 3} \cdot \mathrm{HBr})$ formed the first AMT prodrug $\mathbf{2 4}$. The concentration of the reaction was critical to obtain a reasonable yield, as previously published by Montgomery et al. ${ }^{57}$ for similar substrates. The last step consisted of alkaline hydrolysis of $\mathbf{2 4}$ to form the second AMT prodrug 25. These compounds represent the proposed set of phenylboronic acid-based AMT prodrugs in which the promoiety is attached to the secondary aniline group, bearing methylester protected (24) or free carboxylic acids (25).

Scheme 3. Synthesis of AMT prodrugs 24 and $25^{\mathrm{a}}$<smiles>Nc1ccc(C(=O)O)cc1</smiles>

18<smiles>O=C(Nc1ccc(C(=O)O)cc1)OCc1ccccc1</smiles>

19 $\stackrel{\mathrm{b},{ }^{\mathrm{c}}}{\longrightarrow}$<smiles>CCC(=O)C(CCC(=O)OC)NC(=O)c1ccc(NC(=O)c2ccccc2)cc1</smiles>

20

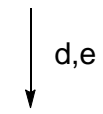<smiles></smiles><smiles>OBO</smiles><smiles>COC(=O)CC[C@H](NC(=O)c1ccc(NCc2ccc(C)cc2)cc1)C(=O)OC</smiles><smiles>CCCCC</smiles><smiles>COC(=O)CC[C@H](NC(=O)c1ccc(N)cc1)C(=O)OC</smiles>

$\mathrm{HO}_{-\mathrm{B}^{-}} \mathrm{OH}$<smiles>[Z4]c1ccc(CN(Cc2cnc3nc(N)nc(N)c3n2)c2ccc(C(=O)N[C@@H](CCC(=O)OC)C(=O)OC)cc2)cc1</smiles><smiles>C=CC</smiles><smiles>Nc1nc(N)c2nc(CN(Cc3ccc(B(O)O)cc3)c3ccc(C(=O)N[C@@H](CCC(=O)O)C(=O)O)cc3)cnc2n1</smiles> 
aReagents and conditions: (a) $\mathrm{CbzCl}, \mathrm{NaHCO}_{3}, \mathrm{H}_{2} \mathrm{O} /$ dioxane, $21^{\circ} \mathrm{C}, 2 \mathrm{~h}$ (89\%). (b) $\mathrm{SOCl}_{2}$, DMF, $\mathrm{CH}_{2} \mathrm{Cl}_{2}$, reflux, 24 h. (c) 9. $\mathrm{HCl}, \mathrm{Et}_{3} \mathrm{~N}, \mathrm{CH}_{2} \mathrm{Cl}_{2}, 21^{\circ} \mathrm{C}, 2 \mathrm{~h}$ (>95\%). (d) $\mathrm{H}_{2}, \mathrm{Pd} / \mathrm{C}, \mathrm{MeOH}, 21^{\circ} \mathrm{C}, 12$ h. (e) $\mathrm{HCl}$ in $\mathrm{Et}_{2} \mathrm{O}$ (>95\%). (f) $\mathrm{NaBH}_{4}, \mathrm{MeOH}, 21^{\circ} \mathrm{C}, 24 \mathrm{~h}$ (67\%). (g) DMA, $55^{\circ} \mathrm{C}, 3$ days (43\%). (h) $\mathrm{NaOH}, \mathrm{H}_{2} \mathrm{O}, 21^{\circ} \mathrm{C}, 5 \mathrm{~min}(40 \%)$.

Activation of prodrugs. For a proof-of-principle of the prodrug strategy, a study on the activation of 11-13, 17, 24, and 25 under patho-physiological concentrations of $\mathrm{H}_{2} \mathrm{O}_{2}$ was performed. The experiment consisted on the incubation of test compounds in a 30\% DMSO in PBS mixture at a concentration of $50 \mu \mathrm{M}$ and $\mathrm{H}_{2} \mathrm{O}_{2}$ concentration found in inflammatory tissue (0.5 mM, 10 equiv.) at $37{ }^{\circ} \mathrm{C}$. The activation was followed by RP-UPLC-MS (see Figure S1 and Figure S2 for examples on prodrug 17 and 25 chromatograms, respectively). Negative controls (no $\mathrm{H}_{2} \mathrm{O}_{2}$ addition) were performed in parallel (Figure S3). The rationale behind the substitution of a hydrogen atom in the ortho-position of the phenylboronic acid promoiety by a methyl group or a fluorine atom was the reactivity towards oxidative deboronation. Interestingly, prodrugs 11-13 were activated and released 10 within less than 3 h (>95\% conversion by UPLC-MS), therefore no effects on the reaction rate by ortho-substituents was observed under the conditions tested (Figure 2, left). Furthermore, 17 was activated within the same time frame, releasing exclusively MTX, with no significant difference compared to 11-13. The plot of the formation of prodrug activation products versus time can be found in the SI (Figure S4). Moreover, a concentration dependent release of drug was observed as determined in an activation assay using different concentrations of $\mathrm{H}_{2} \mathrm{O}_{2}$ (see Figure S5). 

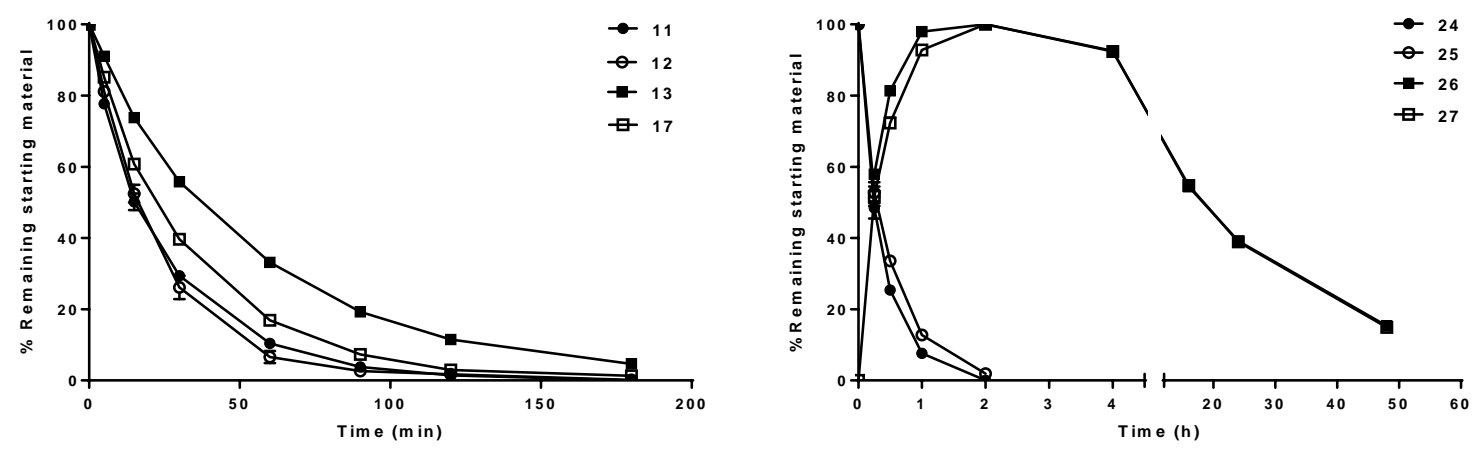

Figure 2. Activation of MTX prodrugs 11-13 and 17 (left), and AMT-prodrugs 24 and 25, as well as formation and disappearance of intermediates $\mathbf{2 6}$ and 27 (right). The experiment was carried out at a compound concentration of $50 \mu \mathrm{M}$ and $0.5 \mathrm{mM} \mathrm{H}_{2} \mathrm{O}_{2}$ (10 equiv.) in a mixture of 30\% DMSO in PBS at $37^{\circ} \mathrm{C}$. Hidden error bars are smaller than symbols.

The activation of AMT prodrugs 24 and 25 was also examined. Full consumption of prodrugs was observed in a similar timeframe compared to the MTX prodrugs (Figure 2, right). AMT prodrugs did not release AMT nor $\mathbf{2 8}$ within the first two hours of incubation, but instead afforded the corresponding phenol intermediates 26 and 27 (Scheme 4). After 2 h of assay initiation, full disappearance of the prodrugs was observed and $\mathbf{2 6}$ and $\mathbf{2 7}$ started to slowly release AMT and $\mathbf{2 8 ,}$ in a $\mathrm{H}_{2} \mathrm{O}_{2}$ concentration independent manner as studied in a separate assay (see Figure S5). Full formation of products was not observed even after $48 \mathrm{~h}$ of incubation. The formation of the relatively stable intermediates $\mathbf{2 6}$ and $\mathbf{2 7}$ could potentially allow them to disperse from the inflammatory environment and exert non-selective drug actions upon AMT release, unlike for the MTX-prodrugs 11-13 and 17, where phenol intermediates were not observed due to the faster selfimmolation. This will have to be further evaluated in a future study of the AMT prodrugs.

Scheme 4. Activation of AMT prodrugs 24 and 25 with $\mathrm{H}_{2} \mathrm{O}_{2}$ to form the intermediates $\mathbf{2 6}$ and 27, respectively, which slowly release $\mathbf{2 8}$ and AMT. 
<smiles>[R7]OC(=O)CC[C@H](NC(=O)[C@H](CCC([R20])=O)NC(=O)c1ccc(NCc2cnc3nc(N)nc(N)c3n2)cc1)C(=O)N[C@@H](Cc1ccc(N(Cc2ccc(O)cc2)Cc2cnc3nc(N)nc(N)c3n2)cc1)C(=O)O[R7]</smiles>

Kinetic solubility. The low solubility of 11-13 and 24 in the $\mathrm{H}_{2} \mathrm{O}_{2}$ activation assay required the use of high concentrations of DMSO (30\%) in PBS. Therefore, the evaluation of the prodrug solubility was prioritized in the development program. Kinetic solubility in PBS was measured at $37{ }^{\circ} \mathrm{C}$ and the results were compared to those determined for the parent drugs, showing low solubility ( $<10 \mu \mathrm{g} / \mathrm{mL}$ ) for the methyl ester prodrugs 11-13 and $\mathbf{2 4}$, according to the guidelines for oral administration in humans and animal dosing formulations (Table 1). On the other hand, prodrugs 17 and 25 showed moderate to good solubility for predicted oral dosing in humans (55 and $48 \mu \mathrm{g} / \mathrm{mL}$, respectively), although still low for animal dosing applications. The low solubility of 11-13 and 24 prompted the decision to select 17 and 25 for further in vitro studies.

Table 1. Kinetic solubility of 11, 12, 13, 17, 24, and 25.

\begin{tabular}{lll} 
Prodrug & \multicolumn{2}{l}{ Kinetic solubility } \\
& $\mu \mathrm{M}$ & $\mu \mathrm{g} / \mathrm{mL}$ \\
\hline $\mathbf{1 1}$ & $3.0 \pm 0.5$ & $2.0 \pm 0.3$ \\
$\mathbf{1 2}$ & $3.1 \pm 1.4$ & $2.1 \pm 0.9$ \\
$\mathbf{1 3}$ & $4.6 \pm 0.9$ & $3.1 \pm 0.6$ \\
$\mathbf{1 7}$ & $87 \pm 2.3$ & $55 \pm 1.5$ \\
$\mathbf{2 4}$ & $4.1 \pm 0.2$ & $2.5 \pm 0.1$ \\
$\mathbf{2 5}$ & $83 \pm 0.6$ & $48 \pm 0.4$ \\
MTX & $2137 \pm 0.0$ & $970 \pm 0.0$ \\
AMT & $>1000 \pm 0.0$ & $>440 \pm 0.0$
\end{tabular}


Chemical (pH 7.4), SGF, SIF, plasma, and metabolic stability. The stability of 17 and 25 was evaluated in different relevant physiological environments including chemical stability at blood pH 7.4 as well as in simulated gastric fluid (SGF), simulated intestinal fluid (SIF), human and mouse plasma and liver microsomes. Firstly, the half-lives $\mathrm{t}_{1 / 2}$ of $\mathbf{1 7}$ and $\mathbf{2 5}$ in PBS (pH 7.4) at 37 ${ }^{\circ} \mathrm{C}$ were determined to 238 and 577 h, respectively, with stabilities higher than $90 \%$ after 24 h in both cases (Table 2 and Figure S6). Secondly, the stability in SGF and SIF was studied and halflives calculated to 8 and 770 h in SGF, and 239 and 866 h in SIF for 17 and 25, respectively (Table 2 and Figure S7). The shorter half-life of $\mathbf{1 7}$ in SGF was found to be pH-dependent rather than a result of enzymatic hydrolysis (Figure S7). Thirdly, the stability in human and mouse plasma proved to be high, with $70 \%$ and $82 \%$ of $\mathbf{1 7}$ and 25 remaining after 24 h in human plasma, respectively, and 62\% and 91\% after $8 \mathrm{~h}$ in mouse plasma (see Figure S8). Their half-lives were calculated using first order kinetics and the results are shown in Table 2. Lastly, the metabolic stability was evaluated by the determination of intrinsic clearance (CLint) in human and mouse pooled liver microsomes. Intrinsic clearance of $\mathbf{1 7}$ and 25 was calculated to 22 and $1.2 \mu \mathrm{L} / \mathrm{min} / \mathrm{mg}$ respectively in human microsomes, while 6.4 and $2.6 \mu \mathrm{L} / \mathrm{min} / \mathrm{mg}$ in mouse microsomes (Table 2 and Figure S9), indicating their high metabolic stability.

Table 2. Chemical (pH 7.4), SGF, SIF, plasma, and metabolic stabilities of prodrug candidates 17 and 25.

\begin{tabular}{|c|c|c|c|c|c|c|c|}
\hline & $\begin{array}{l}\text { Chemical } \\
\text { Stability } \\
\text { (pH 7.4) }\end{array}$ & $\begin{array}{c}\text { SGF } \\
\text { Stability }\end{array}$ & $\begin{array}{c}\text { SIF } \\
\text { Stability }\end{array}$ & $\begin{array}{l}\text { Human } \\
\text { Plasma } \\
\text { Stability }\end{array}$ & $\begin{array}{l}\text { Mouse } \\
\text { Plasma } \\
\text { Stability }\end{array}$ & $\begin{array}{c}\text { Human } \\
\text { Microsomal } \\
\text { Stability }\end{array}$ & $\begin{array}{c}\text { Mouse } \\
\text { Microsomal } \\
\text { Stability }\end{array}$ \\
\hline Prodrug & $t_{1 / 2}(h)$ & $\mathbf{t}_{1 / 2}(\mathrm{~h})$ & $\mathbf{t}_{1 / 2}(\mathrm{~h})$ & $\mathbf{t}_{1 / 2}(\mathrm{~h})$ & $t_{1 / 2}(h)$ & $\begin{array}{c}C_{\text {int }} \\
(\mu \mathrm{L} / \mathrm{min} / \mathrm{mg})\end{array}$ & $\begin{array}{c}\mathrm{CL}_{\mathrm{int}} \\
(\mu \mathrm{L} / \mathrm{min} / \mathrm{mg})\end{array}$ \\
\hline 17 & 238 & 8 & 239 & 70 & 17 & 2.2 & 6.4 \\
\hline 25 & 577 & 770 & 866 & 56 & 63 & 1.2 & 2.6 \\
\hline
\end{tabular}


Anti-arthritic efficacy and preliminary toxicity. The efficacy of the prodrug candidates $\mathbf{1 7}$ and 25 was evaluated in the collagen type-II induced arthritis (CIA) mouse model. This model has been found to be characterised by oxidative stress ${ }^{58}$ and increased concentrations of $\mathrm{H}_{2} \mathrm{O}_{2}$ in the joint tissue, paws and limbs, ${ }^{59,60}$ hence it represents a good model for the evaluation of the prodrug concept. Prior to the in vivo analysis, the prodrug concept was evaluated in vitro for $\mathbf{1 7}$ and 25. To this end, the cell viability inhibition of the prodrugs against two MTX- and AMTsensitive cancer cell lines, NCI-H460 (lung cancer) and MCF-7 (breast cancer), ${ }^{61}$ was tested. The prodrugs showed significantly reduced efficacy in the two cell lines when applied directly to the cells as compared to when they were activated by pre-incubation with non-cytotoxic concentration of $\mathrm{H}_{2} \mathrm{O}_{2}$ (Figures S10-S12). Additionally, the IC 50 values of the pre-activated prodrugs $\mathbf{1 7}$ and 25 showed comparable biological activity to MTX and AMT (Figure S13 and S14) in the two selected cancer cell lines. A detailed description of the assays can be found in the SI.

The in vivo anti-arthritic efficacy and preliminary toxicity study was performed using a therapeutic intervention set up in the CIA model and the parent drugs MTX and AMT were included as treatment controls. Vehicle control (2\% DMSO in PBS), MTX (7.0 mg/kg), and equimolar doses of AMT, 17, and $\mathbf{2 5}$ were i.p. administered on a daily basis for two weeks, starting at onset of disease (day 27 after first immunization). Mean arthritis severity score and average animal body weight were measured three times per week. Reduced incidence of arthritis and reduction of macroscopic arthritis score was observed both for the drugs and prodrugs in comparison to the control group (vehicle) (Figure 3, left). Additionally, remission of arthritis started to be detected at the end of the study for MTX, 17, and 25, with no statistically significant difference in efficacy between them. Interestingly, the AMT-group had to be sacrificed at day 33 due to significant toxicity measured as decreased average body weight in the group, while the 
AMT prodrug 25 did not show any sign of side-effects (Figure 3, right). Progressive weight loss was observed in the MTX-group towards the end of the study but not in the group treated with $\mathbf{1 7}$. These results indicate the great potential of $\mathbf{1 7}$ and $\mathbf{2 5}$ as prodrugs of MTX and AMT, respectively, showing comparable efficacy in managing arthritis development and control of disease activity, and reducing side-effects compared to the parent drugs.
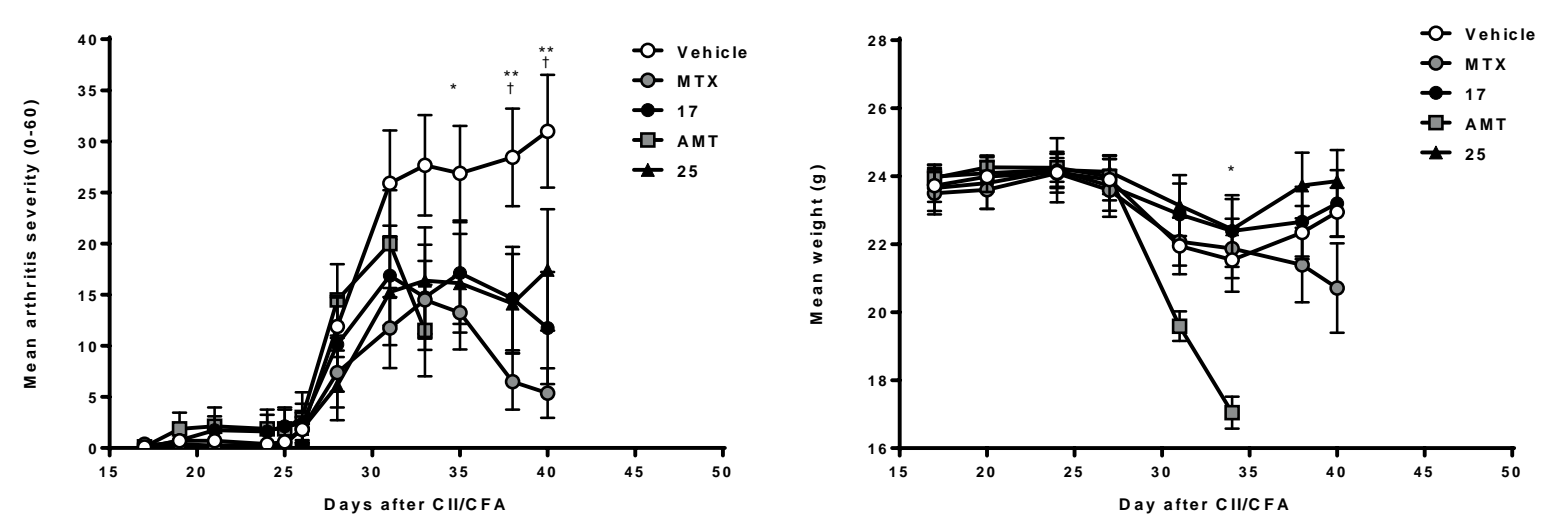

Figure 3. Suppression of CIA development in DBA/1J mice (left) after treatment with MTX (7 $\mathrm{mg} / \mathrm{kg})$ and equimolar amounts of AMT (6.8 mg/kg), $17(9.7 \mathrm{mg} / \mathrm{kg})$, and $25(8.8 \mathrm{mg} / \mathrm{kg})(\mathrm{n}=8$ per group). Mice were given the indicated dose of test compound once per day, starting on day 27, and arthritis scoring was performed three times per week. Data represents mean values of arthritic score \pm SEM. Statistics were calculated using a one-tailed non parametric Mann-Whitney. ${ }^{*} \mathrm{p}<$ 0.05 and ${ }^{* *} \mathrm{p}<0.01$ between MTX and vehicle and $\dagger \mathrm{p}<0.05$ between 17 and vehicle. General health of mice (right) evaluated three times per week as the average body weight in groups of animals $(\mathrm{n}=8)$ tested with vehicle, MTX, AMT, 17, and 25. Data represents mean values of bodyweight \pm SEM. ${ }^{*} \mathrm{p}<0.05$ between AMT and vehicle. One animal in the vehicle and the 25 groups were sacrificed pre-termination due to high arthritis scores. The AMT group was removed at day 33 due to decline in health. AMT, aminopterin; CIA, collagen induced-arthritis; CII, collagen type-II; MTX, methotrexate.

Although no toxicity associated to prodrugs $\mathbf{1 7}$ and $\mathbf{2 5}$ has been observed in the animal assays performed, it is of relevance for future studies of the potential toxicities to also account for the release of quinone methides as prodrug activation end-product. Their reactivity and toxicity has been linked and reviewed elsewhere, ${ }^{62}$ and prior studies have demonstrated that it is possible to modulate these factors through judicious choice of the substitution pattern on the quinone methides released. Noteworthy, quinone moieties are known in long-term use marketed drugs, ${ }^{62}$ and newly 
developed ROS-sensitive drug delivery systems which employ phenyl boronates as the responsive chemical entity have shown good safety profiles after long-term administration in mice. ${ }^{63}$

\section{CONCLUSION}

In this report, we have described the synthesis of new arylboronic acid-based hydrogen peroxidesensitive prodrugs of MTX and AMT for site-selective delivery of drugs to inflammatory tissues associated to RA with the aim of reducing side effects in MTX and AMT RA therapy. Among the set of prodrugs synthesized, 17 and 25 showed moderate to good solubility, high chemical stability, high stability in simulated gastrointestinal fluids, and high plasma and metabolic stabilities both in human and mouse plasma and liver microsomes. Their comparable efficacy and lower toxicity in comparison to parental drugs was identified using a CIA mouse model of RA. Future work will focus on additional in vivo studies to establish optimal dosing and to map toxicity in more detail to hopefully advance these promising prodrugs into clinical evaluations.

\section{EXPERIMENTAL SECTION}

\section{General considerations}

Unless otherwise stated, commercially available reagents were used without further purification and all solvents were of HPLC quality. Reactions under nitrogen atmosphere were performed in oven- or flame-dried glassware and anhydrous solvents. Anhydrous $\mathrm{CH}_{2} \mathrm{Cl}_{2}, \mathrm{CH}_{3} \mathrm{CN}, \mathrm{THF}, \mathrm{DMF}$, and toluene were obtained from Innovative Technology PS-MD-7 Pure solve solvent purification system. All reactions were monitored by thin-layer chromatography (TLC) and/or reversed-phased

ultra-performance liquid chromatography mass spectrometry (RP-UPLC-MS). Analytical TLC was conducted on Merck aluminium sheets covered with silica 
(C60). The plates were either visualized under UV-light or stained by dipping in a developing agent followed by heating. $\mathrm{KMnO}_{4}\left(3 \mathrm{~g}\right.$ in water $(300 \mathrm{~mL})$ along with $\mathrm{K}_{2} \mathrm{CO}_{3}(20 \mathrm{~g})$ and $5 \%$ aqueous $\mathrm{NaOH}(5 \mathrm{~mL})$ ) or Ninhydrin (3 g in a mixture of $n$-butanol $(200 \mathrm{~mL})$ and $\mathrm{AcOH}(6 \mathrm{~mL}))$ were used as developing agents. Flash column chromatography was performed using Matrex 60 $\AA$, $35-70 \mu$ silica gel. All new compounds were characterized by IR, ${ }^{1} \mathrm{H} N M R,{ }^{13} \mathrm{C}$ NMR, HRMS (ESI) and melting point (m.p.) when applicable. For recording of ${ }^{1} \mathrm{H} N \mathrm{NR}$ and ${ }^{13} \mathrm{C}$ NMR a Bruker Ascend with a Prodigy cryoprobe (operating at $400 \mathrm{MHz}$ for proton and $101 \mathrm{MHz}$ for carbon) was used. Unless otherwise stated, all NMR spectra were recorded at $25^{\circ} \mathrm{C}$. The chemical shifts $(\delta)$ are reported in parts per million (ppm) and the coupling constants $(J)$ in Hz. For spectra recorded in $\mathrm{CDCl}_{3}$, signal positions were measured relative to the signal for $\mathrm{CHCl}_{3}\left(7.26 \mathrm{ppm}\right.$ for ${ }^{1} \mathrm{H} \mathrm{NMR}$ and 77.16 ppm for ${ }^{13} \mathrm{C}$ NMR). For spectra recorded in DMSO- $\mathrm{d}_{6}$ signal positions were measured relative to the signal for DMSO ( $\delta 2.50 \mathrm{ppm}$ for ${ }^{1} \mathrm{H}$ NMR and $39.52 \mathrm{ppm}$ for ${ }^{13} \mathrm{C}$ NMR). For spectra recorded in $\mathrm{D}_{2} \mathrm{O}$ signal positions were measured relative to the signal for $\mathrm{H}_{2} \mathrm{O}(\delta 4.79 \mathrm{ppm}$ for ${ }^{1} \mathrm{H}$ NMR at $\left.25^{\circ} \mathrm{C}\right) \cdot{ }^{64}$ The ${ }^{13} \mathrm{C}$ NMR signal of the ipso carbon to the boron atom was not observed in any characterized compound, aulthough they were identified by the characteristic HMBC correlation signals. Infrared (IR) spectra were recorded on a Bruker Alpha-P FT-IR (Bruker) instrument. Neat application into the apparatus was used for all compounds. Transmittance units were plotted in the y axis and wavenumber $\left(\mathrm{cm}^{-1}\right)$ on the $\mathrm{x}$ axis. Optical rotations were measured on a Perkin Elmer Model 241 Polarimeter (cuvette $1.0 \mathrm{~mL}, 100 \mathrm{~mm}$ ) using a sodium source lamp (589 nm, $20^{\circ} \mathrm{C}$ ). Melting points (m.p.) were recorded using a Stuart melting point SMP30, and reported in ${ }^{\circ} \mathrm{C}$, uncorrected. Analytical RP-UPLC-MS (ESI) analysis was performed on a Waters AQUITY RP-UPLC system equipped with a diode array detector using a Thermo accucore C18 column (d $2.6 \mu \mathrm{m}, 2.1$ x $50 \mathrm{~mm}$; column temp: $50^{\circ} \mathrm{C}$; flow: $0.6 \mathrm{~mL} / \mathrm{min}$ ). Four different methods 
were use. Method A: eluents A $\left(0.1 \% \mathrm{HCO}_{2} \mathrm{H}\right.$ in milli-Q water) and $\mathrm{B}\left(0.1 \% \mathrm{HCO}_{2} \mathrm{H}\right.$ in $\left.\mathrm{CH}_{3} \mathrm{CN}\right)$ were used in a linear gradient (5\% B to $100 \%$ B) in a total run time of 2.6 min. Method B: eluents A $\left(0.1 \% \mathrm{HCO}_{2} \mathrm{H}\right.$ in $\left.\mathrm{H}_{2} \mathrm{O}\right)$ and $\mathrm{B}\left(0.1 \% \mathrm{HCO}_{2} \mathrm{H}\right.$ in $\left.\mathrm{CH}_{3} \mathrm{CN}\right)$ were used in a linear gradient (5\% $\mathrm{B}$ to $100 \% \mathrm{~B}$ ) in a total run time of $5.0 \mathrm{~min}$. Method C: eluents A (10 mM NH $4 \mathrm{OAc}$ in milli-Q water) and $\mathrm{B}\left(0.1 \% \mathrm{NH}_{4} \mathrm{OAc}\right.$ in milli-Q water/MeCN, $90 / 10$, v/v) were used in a linear gradient (5\% B to $100 \% \mathrm{~B})$ in a total run time of $2.6 \mathrm{~min}$. Method D: eluents $\mathrm{A}\left(0.1 \% \mathrm{NH}_{4} \mathrm{OAc}\right.$ in $\left.\mathrm{H}_{2} \mathrm{O}\right)$ and $\mathrm{B}$ $\left(0.1 \% \mathrm{NH}_{4} \mathrm{OAc}\right.$ in $\left.\mathrm{CH}_{3} \mathrm{CN}\right)$ were used in a linear gradient (5\% B to $100 \% \mathrm{~B}$ ) in a total run time of 5.0 min. The LC system was coupled to a SQD mass spectrometer operating in both positive and negative electrospray modes. The temperature for all recordings was $20^{\circ} \mathrm{C}$. Analytical LC-HRMS (ESI) analysis was performed on an Agilent 1100 RP-LC system equipped with a diode array detector using a Phenomenex Luna C18 column ( $d 3 \mu \mathrm{m}, 2.1$ x 50 mm; column temp: $40{ }^{\circ} \mathrm{C}$; flow: $0.4 \mathrm{~mL} / \mathrm{min})$. Eluents $\mathrm{A}\left(0.1 \% \mathrm{HCO}_{2} \mathrm{H}\right.$ in $\left.\mathrm{H}_{2} \mathrm{O}\right)$ and $\mathrm{B}\left(0.1 \% \mathrm{HCO}_{2} \mathrm{H}\right.$ in $\left.\mathrm{CH}_{3} \mathrm{CN}\right)$ were used in a linear gradient (20\% B to $100 \%$ B) in a total run time of $15 \mathrm{~min}$. The LC system was coupled to a Micromass LCT orthogonal time-of-flight mass spectrometer equipped with a Lock Mass probe operating in positive or negative electrospray mode. Purification of reactions by preparative RPHPLC was performed on a Waters Alliance reverse-phase HPLC system consisting of a Waters 2545 Binary Gradient Module equipped with either an xBridge BEH C18 OBD Prep Column (130 Å, $5 \mu \mathrm{m}, 30$ x 150 mm) or an xBridge Peptide BEH C18 OBD Prep Column (130 Å, $5 \mu \mathrm{m}, 19$ mm x $100 \mathrm{~mm}$ ) both operating at $20^{\circ} \mathrm{C}$ and a flow rate of $20 \mathrm{~mL} / \mathrm{min}$, a Waters Photodiode Array Detector (detecting at 210-600 nm), a Waters UV Fraction Manager, and a Waters 2767 Sample Manager. Elution was carried out in a reversed-phase gradient fashion combining A1 (0.1\% $\mathrm{HCO}_{2} \mathrm{H}$ in milli-Q water) and $\mathrm{B} 1\left(0.1 \% \mathrm{HCO}_{2} \mathrm{H}\right.$ in $\left.\mathrm{CH}_{3} \mathrm{CN}\right)$ or $\mathrm{A} 2\left(5 \mathrm{mM} \mathrm{NH} \mathrm{OAc} \mathrm{On} \mathrm{H}_{2} \mathrm{O}\right)$ and B2 (5 mM NH $4{ }_{4} \mathrm{OAc}$ in $\mathrm{CH}_{3} \mathrm{CN}$ ): 5\% B to $70 \% \mathrm{~B}$ in $10 \mathrm{~min}$, hold for $3.5 \mathrm{~min}$, then $70 \%$ B to $100 \%$ 
B in 1.5 min, and hold 3 minutes. Total run time: 20 min. The purity of the compounds was assessed by RP-UPLC-UV and NMR, and purities $\geq 95 \%$ were considered acceptable for evaluation purposes both in vitro and in vivo assays.

\section{Synthesis}

\section{3-Methyl-4-(4,4,5,5-tetramethyl-1,3,2-dioxaborolan-2-yl)benzyl carbonochloridate (4b).}

General procedure A: a suspension of $\mathbf{3 b}(0.9 \mathrm{~g}, 5.4 \mathrm{mmol})$ and pinacol $(0.7 \mathrm{~g}, 6.0 \mathrm{mmol})$ in anhydrous THF (25 mL) was refluxed for $16 \mathrm{~h}$ under an $\mathrm{N}_{2}$ atmosphere. The solids dissolved during the reaction time. Then, the mixture was concentrated in vacuo and the residue purified by flash column chromatography on silica gel using a mixture of $\mathrm{CH}_{2} \mathrm{Cl}_{2} / \mathrm{EtOAc}(9 / 1, \mathrm{v} / \mathrm{v})$ as the eluent to give the title compound $\mathbf{4 b}$ as a clear oil (1.27 g, 95\%) which solidified upon storage in the refrigerator. $\mathrm{R}_{\mathrm{f}}=0.84$ (silica, $\mathrm{CH}_{2} \mathrm{Cl}_{2} / \mathrm{EtOAc}, 1 / 1$, v/v); m.p.: $38.5-41.3^{\circ} \mathrm{C}$; IR (neat, $\mathrm{cm}^{-1}$ ): 3390.6, 2978.1, 2925.3, 2867.7, 1609.0, 1347.1, 335.9; ${ }^{1} \mathrm{H}$ NMR (400 MHz, $\left.\mathrm{CDCl}_{3}\right) \delta 7.76(\mathrm{~d}$, $J=7.4 \mathrm{~Hz}, 1 \mathrm{H}), 7.17-7.09$ (m, 2H), 4.67 (s, 2H), 2.54 (s, 3H), 1.34 (s, 12H); ${ }^{13} \mathrm{C}$ NMR (101 $\left.\mathrm{MHz}, \mathrm{CDCl}_{3}\right) \delta 145.5,143.6,136.4,128.3,123.2,83.6,65.4,25.0,22.3 ;$ HRMS (ESI) m/z: calcd for $\mathrm{C}_{14} \mathrm{H}_{22} \mathrm{BO}_{3}[\mathrm{M}+\mathrm{Na}]^{+}$271.1476, found 271.1512.

\section{(3-Fluoro-4-(4,4,5,5-tetramethyl-1,3,2-dioxaborolan-2-yl)phenyl)methanol (4c). Following} general procedure A using 3c $(0.90 \mathrm{~g}, 5.30 \mathrm{mmol})$, the title compound $4 \mathbf{c}$ was afforded as a clear oil (1.26 g, 94\%) after purification by flash column chromatography on silica gel using a mixture of $\mathrm{CH}_{2} \mathrm{Cl}_{2} / \mathrm{EtOAc}(9 / 1, \mathrm{v} / \mathrm{v})$ as the eluent. The oil became a white solid upon storage in the refrigerator. $\mathrm{R}_{\mathrm{f}}=0.71$ (silica, eluent $\mathrm{CH}_{2} \mathrm{Cl}_{2} / \mathrm{EtOAc}, 1 / 1$, v/v); m.p.: $52.5-56.4{ }^{\circ} \mathrm{C}\left(\mathrm{Litt}^{65}{ }^{65} 35-38\right.$ ); IR (neat, $\mathrm{cm}^{-1}$ ): 3424.6, 2978.6, 2932.3, 2864.3, 1624.1, 1351.8; ${ }^{1} \mathrm{H}$ NMR (400 MHz, $\left.\mathrm{CDCl}_{3}\right) \delta$ $7.77-7.67$ (m, 1H), 7.12 (d, $J=7.6 \mathrm{~Hz}, 1 \mathrm{H}), 7.06$ (d, $J=10.1 \mathrm{~Hz}, 1 \mathrm{H}), 4.72$ (s, 2H), 1.36 (s, 
12H); ${ }^{65}{ }^{13} \mathrm{C}$ NMR $\left(101 \mathrm{MHz}, \mathrm{CDCl}_{3}\right) \delta 167.6(\mathrm{~d}, J=251.4 \mathrm{~Hz}), 147.2(\mathrm{~d}, J=8.0 \mathrm{~Hz}), 137.2(\mathrm{~d}, J$ $=8.4 \mathrm{~Hz}), 121.7$ (d, $J=2.9 \mathrm{~Hz}), 113.4(\mathrm{~d}, J=24.7 \mathrm{~Hz}), 84.0,64.6,25.0{ }^{65}$

4-(4,4,5,5-tetramethyl-1,3,2-dioxaborolan-2-yl)benzyl carbonochloridate (5a). General procedure B: a solution of $4 \mathbf{a}(2.0 \mathrm{~g}, 8.54 \mathrm{mmol})$ in anhydrous dioxane $(25 \mathrm{~mL})$ was treated with phosgene (20\% in toluene, $22.6 \mathrm{~mL}, 42.7 \mathrm{mmol}$ ) and the reaction was stirred for $20 \mathrm{~h}$ under an $\mathrm{N}_{2}$ atmosphere at $21{ }^{\circ} \mathrm{C}$. The mixture was concentrated in vacuo, redissolved and concentrated with toluene (2x) to afford the crude title compound $5 \mathbf{a}$ as a clear oil (2.5 g, > 95\%). The crude chloroformate was used in subsequent reactions within few hours after its isolation. ${ }^{1} \mathrm{H}$ NMR (400 MHz, $\left.\mathrm{CDCl}_{3}\right) \delta 7.84$ (d, $\left.J=8.1 \mathrm{~Hz}, 2 \mathrm{H}\right), 7.38$ (d, $\left.J=8.1 \mathrm{~Hz}, 2 \mathrm{H}\right), 5.31$ (s, 2H), 1.35 (s, 12H); ;6 ${ }^{13} \mathrm{C}$ NMR $\left(101 \mathrm{MHz}, \mathrm{CDCl}_{3}\right) \delta 150.8,136.2,135.4,128.0,84.2,73.4,25.0 .{ }^{66}$

\section{3-Methyl-4-(4,4,5,5-tetramethyl-1,3,2-dioxaborolan-2-yl)benzyl carbonochloridate (5b).}

Following general procedure B using $\mathbf{4 b}(1.2 \mathrm{~g}, 4.8 \mathrm{mmol})$, the title compound $5 \mathbf{b}$ was afforded as a clear oil (1.5 g, >95\%). The crude chloroformate was used in subsequent reactions within few hours after its isolation. ${ }^{1} \mathrm{H}$ NMR $\left(400 \mathrm{MHz}, \mathrm{CDCl}_{3}\right) \delta 7.78(\mathrm{~d}, J=8.0 \mathrm{~Hz}, 1 \mathrm{H}), 7.20-7.13(\mathrm{~m}$, 2H), 5.26 (s, 2H), 2.55 (s, 3H), 1.34 (s, 12H); ${ }^{13} \mathrm{C}$ NMR (101 MHz, $\left.\mathrm{CDCl}_{3}\right) \delta 150.8,145.7,136.5$, 135.7, 130.1, 125.0, 83.8, 73.5, 25.0, 22.3.

\section{3-Fluoro-4-(4,4,5,5-tetramethyl-1,3,2-dioxaborolan-2-yl)benzyl carbonochloridate (5c).}

Following general procedure B using $4 \mathrm{c}(1.2 \mathrm{~g}, 4.8 \mathrm{mmol})$, the crude product $5 \mathrm{c}$ was afforded as a white solid (1.5 g, >95\%). The crude chloroformate was used in subsequent reactions within few hours after isolation. ${ }^{1} \mathrm{H}$ NMR $\left(400 \mathrm{MHz}, \mathrm{CDCl}_{3}\right) \delta 7.77(\mathrm{dd}, J=7.5,6.1 \mathrm{~Hz}, 1 \mathrm{H}), 7.15(\mathrm{dd}, J=$ 7.5, $1.3 \mathrm{~Hz}, 1 \mathrm{H}), 7.07$ (dd, $J$ = 9.6, $1.1 \mathrm{~Hz}, 1 \mathrm{H}), 5.29$ (s, 2H), 1.36 (s, 12H); ${ }^{65}{ }^{13} \mathrm{C}$ NMR (101 MHz, 
$\left.\mathrm{CDCl}_{3}\right) \delta 167.7(\mathrm{~d}, J=251 \mathrm{~Hz}), 150.8,138.92(\mathrm{~d}, J=8.3 \mathrm{~Hz}), 137.6$ (d, $\left.J=8.5 \mathrm{~Hz}\right), 123.5(\mathrm{~d}, J=$ $3.2 \mathrm{~Hz}), 115.3$ (d, $J=25.4 \mathrm{~Hz}$ ), 84.3 (s), 72.2 (s), 25.0 (s). ${ }^{65}$

4-((2,4-Diaminopteridin-6-yl)methyl)(methyl)amino)benzoic acid (7). 2,4-Diamino-6(hydroxymethyl)pteridine hydrochloride $\mathbf{6} \cdot \mathrm{HCl}(4.4 \mathrm{~g}, 19 \mathrm{mmol}$ ) was dissolved in hot water (150 $\mathrm{mL}$ ) and after cooling to $21^{\circ} \mathrm{C}$ the solution was neutralized with $1 \mathrm{M}$ aq. $\mathrm{NaOH}$ to $\mathrm{pH} \sim 7$ (ca. 20 $\mathrm{mL}$ ). The formed precipitates were collected by filtration, washed with water, and dried in vacuo over $\mathrm{P}_{2} \mathrm{O}_{5}$ to afford an orange-beige solid corresponding to 2,4-diamino-6(hydroxymethyl)pteridine. The solid was suspended in anhydrous DMA (25 mL) and triphenylphosphine dibromide (18 g, $43 \mathrm{mmol}$ ) was added to the suspension. The turbid and dark mixture was stirred for $24 \mathrm{~h}$ under an $\mathrm{N}_{2}$ atmosphere at $20{ }^{\circ} \mathrm{C}$. Then, 4-aminobenzoic acid (3.0 g, $20 \mathrm{mmol}$ ) was added to the reaction and stirred for an additional three days. The reaction mixture was poured into $250 \mathrm{~mL}$ of $0.33 \mathrm{~N} \mathrm{NaOH}$ and the precipitate was filtered off. The filtrate was neutralized with $10 \%$ aq. acetic acid (ca. $20 \mathrm{~mL}$ ) and the precipitate formed upon neutralization was filtered off, washed with water, triturated over $\mathrm{MeOH}$, filtered, and dried in vacuo to afford the title compound 7 as an orange-beige solid (5.70 g, 91\%). m.p.: > $240{ }^{\circ} \mathrm{C}$ (decomp.) (lit. ${ }^{52}$ $242{ }^{\circ} \mathrm{C}$ ); IR (neat, $\mathrm{cm}^{-1}$ ): 3378.7, 3279.5, 2233.3, 1663.6, 1598.6, 1288.4, 1186.0; ${ }^{67}{ }^{1} \mathrm{H}$ NMR (400 MHz, DMSO-d $\left.{ }_{6}\right) \delta 12.15$ (br s, 1H), $8.63(\mathrm{~s}, 1 \mathrm{H}), 8.17$ (br s, 1H), 7.94 (br s, 1H), 7.73 (d, $J=9.0 \mathrm{~Hz}, 2 \mathrm{H}$ ), 7.04 (br s, 2H), 6.83 (d, $J=9.0 \mathrm{~Hz}, 2 \mathrm{H}), 4.81$ (s, 2H), 3.23 (s, 3H), ${ }^{26}{ }^{13} \mathrm{C} \mathrm{NMR}$ (101 MHz, DMSO-d 6 ) $\delta 167.8,163.2,161.1,152.3,149.5,147.8,131.5,122.2,118.1,111.7$, 100.0, 55.2, 39.6.

Dimethyl L-glutamate hydrochloride $(9 \cdot \mathrm{HCl})$. Thionyl chloride $(5.0 \mathrm{~mL}, 68 \mathrm{mmol})$ was added dropwise to $50 \mathrm{~mL}$ of anhydrous $\mathrm{MeOH}$ at $0{ }^{\circ} \mathrm{C}$. The mixture was stirred for $30 \mathrm{~min}$ at the same temperature followed by addition of L-glutamic acid 8 (5.0 g, $34 \mathrm{mmol})$. Then, the reaction was 
stirred under an $\mathrm{N}_{2}$ atmosphere for 3 days at $21^{\circ} \mathrm{C}$ and concentrated in vacuo to afford the title compound $9 \cdot \mathrm{HCl}$ as a colourless solid $(7.19 \mathrm{~g},>95 \%)$. The crude product was used without further purification in the next reactions. m.p.: $63.2-64.0^{\circ} \mathrm{C}$ (lit. ${ }^{68} 77-79$ ); $[\alpha]_{D}^{20}=+25.0$ (c 5.0, $\left.\mathrm{H}_{2} \mathrm{O}\right)^{69}$; IR (neat, $\left.\mathrm{cm}^{-1}\right)$ ): 2952.45, 2902.73, 2852.33, 1728.67 ${ }^{70} ;{ }^{1} \mathrm{H}$ NMR (400 MHz, $\left.\mathrm{D}_{2} \mathrm{O}\right) \delta 4.24-4.19$ (m, 1H), 3.85 (s, 3H), 3.73 (s, 3H), 2.65 (td, $J=7.3,2.2 \mathrm{~Hz}, 2 \mathrm{H}), 2.37-2.13(\mathrm{~m}, 2 \mathrm{H}) ;{ }^{70}{ }^{13} \mathrm{C} \mathrm{NMR}$ $\left(101 \mathrm{MHz}, \mathrm{D}_{2} \mathrm{O}\right) \delta 174.8,170.2,53.6,52.4,52.0,29.2,24.7 .^{70}$

\section{Dimethyl (4-(((2,4-diaminopteridin-6-yl)methyl)(methyl)amino)benzoyl)-L-glutamate (10).}

To a solution of 7 (3.0 g, $9.2 \mathrm{mmol})$ in anhydrous DMF $(80 \mathrm{~mL})$ was added $\mathrm{Et}_{3} \mathrm{~N}(6.4 \mathrm{~mL}, 46.1$ mmol) followed by PyBOP (6.5 g, $12.4 \mathrm{mmol})$. The mixture was stirred for 30 min under an $\mathrm{N}_{2}$ atmosphere at $21^{\circ} \mathrm{C}$. Then, $\mathbf{9} \cdot \mathrm{HCl}(2.1 \mathrm{~g}, 9.9 \mathrm{mmol})$ was added and the reaction mixture was stirred for $5 \mathrm{~h}$ at the same temperature. Then, the reaction was filtered through a path of Celite ${ }^{\circledR}$ and the filtrate concentrated in vacuo. Next, the residue was dissolved in a mixture of EtOAc/ $\mathrm{CHCl}_{3}(150$ $\mathrm{mL}, 1 / 1)$ and poured into $750 \mathrm{~mL}$ of $\mathrm{Et}_{2} \mathrm{O}$ at $0{ }^{\circ} \mathrm{C}$ under strong stirring. The resultant suspension was filtered off, washed with $\mathrm{Et}_{2} \mathrm{O}$ and cold water, triturated in hot $\mathrm{MeOH}$, and filtered off again. The resultant orange solid wash purified by flash column chromatography on silica gel using a mixture of $\mathrm{CH}_{2} \mathrm{Cl}_{2} / \mathrm{MeOH}(92.5 / 7.5, \mathrm{v} / \mathrm{v})$ as the eluent to give the title compound $\mathbf{1 0}$ as a yellow solid (2.39 g, 54\%). $\mathrm{R}_{\mathrm{f}}=0.48$ (silica, $\mathrm{MeOH} / \mathrm{CH}_{2} \mathrm{Cl}_{2}, 1 / 9$, v/v); m.p.: >168.6 (decomp.) (lit. ${ }^{52} 130$ 134); $[\alpha]_{D}^{20}=+2.6$ (c 0.5, DMSO); IR (neat, $\mathrm{cm}^{-1}$ ): 3306.96, 3128.91, 2950.99, 2923.52, 1731.36, 1626.09, 1604.36, 1503.14, 1435.41; ${ }^{1} \mathrm{H}$ NMR (400 MHz, DMSO-d 6 ) $\delta 8.56(\mathrm{~s}, 1 \mathrm{H}), 8.34$ (d, $J=$ $7.4 \mathrm{~Hz}, 1 \mathrm{H}), 7.77-7.69$ (m, 3H), 7.45 (br s, 1H), 6.82 (d, $J=8.8 \mathrm{~Hz}, 2 \mathrm{H}), 6.61$ (br s, 2H), 4.78 (s, 2H), 4.39 (ddd, $J=9.4,7.4,5.6 \mathrm{~Hz}, 1 \mathrm{H}$ ), 3.61 (s, 3H), 3.57 (s, 3H), 3.21 (s, 3H), 2.41 (t, $J=7.4$ Hz, 2H), $2.17-1.72(\mathrm{~m}, 2 \mathrm{H}) ;{ }^{71}{ }^{13} \mathrm{C}$ NMR (101 MHz, DMSO-d 6 ) $\delta$ 172.7, 172.6, 166.4, 162.9, 
162.7, 155.2, 151.0, 149.2, 145.9, 129.0, 121.4, 120.7, 111.0, 54.9, 51.8, 51.7, 51.4, 38.7, 30.0, 25.8; ${ }^{71} \mathrm{HRMS}$ (ESI) m/z: calcd for $\mathrm{C}_{22} \mathrm{H}_{27} \mathrm{~N}_{8} \mathrm{O}_{5}[\mathrm{M}+\mathrm{H}]^{+}$483.2099, found 483.2119 .

\section{(S)-(4-)(((2-Amino-6-)((4-((1,5-dimethoxy-1,5-dioxopentan-2-}

\section{yl)carbamoyl)phenyl)(methyl)amino)methyl)pteridin-4-yl)carbamoyl)oxy)methyl)}

phenyl)boronic acid (11). General procedure C: to a suspension of $\mathbf{1 0}$ (313 $\mathrm{mg}, 0.68 \mathrm{mmol})$ in anhydrous $\mathrm{CH}_{2} \mathrm{Cl}_{2}(25 \mathrm{~mL}$ ) was added DMAP (417 mg, $3.42 \mathrm{mmol}$ ) followed by DIPEA (0.60 $\mathrm{mL}, 3.42 \mathrm{mmol})$. The mixture was cooled to $0{ }^{\circ} \mathrm{C}$ and a solution of $5 \mathbf{a}(1.01 \mathrm{~g}, 3.42 \mathrm{mmol})$ in $\mathrm{CH}_{2} \mathrm{Cl}_{2}(10 \mathrm{~mL})$ was added dropwise. The reaction was allowed to warm to $21{ }^{\circ} \mathrm{C}$ and stirred for $6 \mathrm{~h}$ under an $\mathrm{N}_{2}$ atmosphere. Then, the mixture was diluted with $\mathrm{CH}_{2} \mathrm{Cl}_{2}(100 \mathrm{~mL})$, washed with $0.1 \mathrm{M}$ aq. $\mathrm{HCl}(2 \times 75 \mathrm{~mL})$, sat. aq. $\mathrm{NaHCO}_{3}(2 \times 75 \mathrm{~mL})$, and brine $(75 \mathrm{~mL})$. The organic layer was dried over $\mathrm{Na}_{2} \mathrm{SO}_{4}$, filtered, and concentrated in vacuo to afford a yellow solid that was purified by reversed-phase preparative HPLC. The $\mathrm{CH}_{3} \mathrm{CN} / \mathrm{H}_{2} \mathrm{O}$ collected fractions containing the pinacolate intermediate were combined into a $250 \mathrm{~mL}$ round bottom flask and $\mathrm{HCl}$ cc. $(0.3 \mathrm{~mL}$, $\mathrm{pH} \sim 2$ ) was added. The reaction mixture was stirred for $16 \mathrm{~h}$ at $21^{\circ} \mathrm{C}$ and quenched with sat. aq. $\mathrm{NaHCO}_{3}$ (ca. $50 \mathrm{~mL}$ ). After removal of the $\mathrm{CH}_{3} \mathrm{CN}$ under rotatory evaporation the formed precipitate was filtered off, washed with $\mathrm{H}_{2} \mathrm{O}$ and dried in vacuo to afford the title compound $\mathbf{1 1}$ as a yellow solid (122 mg, 27\%). Additional preparative HPLC purification was sometimes needed in specific substrates. m.p.: $>153.0^{\circ} \mathrm{C}$ (decomp.); $[\alpha]_{D}^{20}=+4.7$ (c 0.32, DMSO); IR (neat, $\mathrm{cm}^{-1}$ ): 3354.4, 3233.1, 2954.7, 1732.5, 1627.5, 1605.2, 1573.9, 1536.9, 1198.5, 1173.2; ${ }^{1} \mathrm{H}$ NMR (400 MHz, DMSO-d 6 ) $\delta 9.88($ br s, 1H), $8.68(\mathrm{~s}, 1 \mathrm{H}), 8.34$ (d, $J=7.5 \mathrm{~Hz}, 1 \mathrm{H}), 8.08$ (s, 2H), 7.82 (d, $J$ $=7.8 \mathrm{~Hz}, 2 \mathrm{H}$ ), 7.72 (d, $J=8.8 \mathrm{~Hz}, 2 \mathrm{H}$ ), 7.43 (d, $J=7.8 \mathrm{~Hz}, 2 \mathrm{H}$ ), 7.27 (br s, 2H), 6.82 (d, $J=8.8$ Hz, 2H), 5.24 (s, 2H), 4.84 (s, 2H), 4.39 (ddd, $J=9.3,7.5,5.7$ Hz, 1H), 3.60 (s, 3H), 3.56 (s, 3H), 3.20 (s, 3H), 2.40 (t, $J=7.4 \mathrm{~Hz}, 2 \mathrm{H}), 2.15-1.90(\mathrm{~m}, 2 \mathrm{H}) ;{ }^{13} \mathrm{C}$ NMR (101 MHz, DMSO-d 6 ) $\delta$ 
172.7, 172.6, 166.4, 162.0, 157.8, 155.1, 151.1, 150.7, 150.3, 148.0, 137.7, 134.2, 129.0, 127.0, 120.9, 120.9, 111.1, 66.7, 54.9, 51.8, 51.7, 51.4, 38.9, 30.0, 25.8. HRMS (ESI) m/z: calcd for $\mathrm{C}_{30} \mathrm{H}_{34} \mathrm{BN}_{8} \mathrm{O}_{9}[\mathrm{M}+\mathrm{H}]^{+}$661.2536, found 661.2566.

\section{(S)-(4-)(((2-Amino-6-)((4-((1,5-dimethoxy-1,5-dioxopentan-2-}

yl)carbamoyl)phenyl)(methyl)amino)methyl)pteridin-4-yl)carbamoyl)oxy)methyl)-2-

methylphenyl)boronic acid (12). Following general procedure $C$ using $5 \mathbf{b}$ (1.45 g, 4.66 mmol), the title compound 12 was afforded as a yellow solid (179 mg, 22\%). m.p.: $>166.0{ }^{\circ} \mathrm{C}$ (decomp.); $[\alpha]_{D}^{20}=+4.0$ (c 0.7, DMSO); IR (neat, $\mathrm{cm}^{-1}$ ): 3340.8, 3230.2, 2951.6, 1741.8, 1604.5, 1510.3, 1197.7, 1166.6, 1028.4; ${ }^{1} \mathrm{H}$ NMR (400 MHz, DMSO-d 6 ) $\delta 9.82$ (s, 1H), 8.69 (s, 1H), 8.34 (d, $J=7.5 \mathrm{~Hz}, 1 \mathrm{H}$ ), 8.02 (s, 2H), 7.72 (d, $J=9.0 \mathrm{~Hz}, 2 \mathrm{H}), 7.46$ (d, $J=8.0 \mathrm{~Hz}, 1 \mathrm{H}), 7.28$ (br s, 2H), $7.23-7.16(\mathrm{~m}, 2 \mathrm{H}), 6.83(\mathrm{~d}, J=9.0 \mathrm{~Hz}, 2 \mathrm{H}), 5.18$ (s, 2H), 4.84 (s, 2H), 4.39 (ddd, $J=9.5,7.5,5.4 \mathrm{~Hz}, 1 \mathrm{H}), 3.61$ (s, 3H), 3.56 (s, 3H), 3.20 (s, 3H), $2.44-2.37$ (m, 5H), $2.13-1.88$ (m, 2H).; ${ }^{13} \mathrm{C}$ NMR (101 MHz, DMSO-d6) $\delta$ 172.7, 172.6, 166.4, 162.0, 157.8, 155.1, 151.0, 150.7, 150.2, 147.9, 141.4, 136.2, 133.3, 129.0, 128.9, 124.3, 120.9, 120.8, 111.1, 66.7, 54.9, 51.8, 51.7, 51.3, 38.9, 29.9, 25.8, 22.1; HRMS (ESI) $\mathrm{m} / \mathrm{z}$ : calcd for $\mathrm{C}_{31} \mathrm{H}_{36} \mathrm{BN}_{8} \mathrm{O}_{9}[\mathrm{M}+\mathrm{H}]^{+}$675.2693, found 675.2720.

\section{(S)-(4-((((2-Amino-6-(((4-)(1,5-dimethoxy-1,5-dioxopentan-2}

\section{yl)carbamoyl)phenyl)(methyl)amino)methyl)pteridin-4-yl)carbamoyl)oxy)methyl)-2-}

fluorophenyl)boronic acid (13). Following general procedure $C$ using 5c (1.30 g, 4.19 mmol), the title compound $\mathbf{1 3}$ was afforded as a yellow solid (237 mg, 34\%). m.p.: $>158.1{ }^{\circ} \mathrm{C}$ (decomp.); $[\alpha]_{D}^{20}=+4.3$ (c 0.6, DMSO); IR (neat, $\mathrm{cm}^{-1}$ ): 3499.4, 3448.3, 3360.5, 3326.1, 3218.7, 2952.9, 1760.0, 1733.0, 1625.6, 1490.3, 1196.3, 1171.6; ${ }^{1} \mathrm{H}$ NMR (400 MHz, DMSO-d 6 ) $\delta 9.95$ (s, 1H), 8.69 (s, 1H), 8.34 (d, $J=7.5 \mathrm{~Hz}, 1 \mathrm{H}), 8.22$ (s, 2H), 7.72 (d, $J=8.8 \mathrm{~Hz}, 2 \mathrm{H}), 7.59$ (t, 
$J=7.0 \mathrm{~Hz}, 1 \mathrm{H}), 7.40-7.20(\mathrm{~m}, 4 \mathrm{H}), 6.83$ (d, $J=8.9 \mathrm{~Hz}, 2 \mathrm{H}), 5.25$ (s, 2H), 4.85 (s, 2H), 4.39 (ddd, $J=9.4,7.5,5.7 \mathrm{~Hz}, 1 \mathrm{H}$ ), 3.61 (s, 3H), 3.56 (s, 3H), 3.20 (s, 3H), 2.41 (t, $J=7.4 \mathrm{~Hz}, 2 \mathrm{H}$ ), 2.16 - $1.86(\mathrm{~m}, 2 \mathrm{H}) ;{ }^{13} \mathrm{C}$ NMR (100 MHz, DMSO-d $)$ ) $\delta 173.2,173.04,166.9,165.9(\mathrm{~d}, J=244.5$ Hz), 162.5, 158.3, 155.6, 151.5, 151.1, 150.7, 148.4, 140.6 (d, $J=8.3 \mathrm{~Hz}), 136.0(\mathrm{~d}, J=9.8 \mathrm{~Hz})$, 129.5, 123.4 (d, $J=2.7 \mathrm{~Hz}), 121.4,121.3,114.5$ (d, $J=25.5 \mathrm{~Hz}), 111.6,66.2,55.4,52.3,52.2$, 51.8, 39.1, 30.4, 26.2; HRMS (ESI) $\mathrm{m} / \mathrm{z}$ : calcd for $\mathrm{C}_{30} \mathrm{H}_{33} \mathrm{BFN}_{8} \mathrm{O}_{9}[\mathrm{M}+\mathrm{H}]^{+}$679.2442, found 679.2455.

\section{Bis(4-methoxybenzyl) (4-((2,4-diaminopteridin-6-yl)methyl)(methyl)amino)benzoyl)-L-}

glutamate (14). A solution of methotrexate $(1.0 \mathrm{~g}, 2.20 \mathrm{mmol})$ in anhydrous DMF (50 mL) was treated with $1,1,3,3$-tetramethylguanidine $(0.55 \mathrm{~mL}, 4.4 \mathrm{mmol})$ at $0{ }^{\circ} \mathrm{C}$ and the mixture was stirred for 30 min under an $\mathrm{N}_{2}$ atmosphere. Then, 4-methoxybenzyl chloride (0.59 mL, $\left.4.4 \mathrm{mmol}\right)$ was added dropwise and the mixture was allowed to warm to $21^{\circ} \mathrm{C}$ and stirred for $24 \mathrm{~h}$. Next, volatiles were removed in vacuo and the crude was purified by flash column chromatography on silica gel using a mixture of $\mathrm{CH}_{2} \mathrm{Cl}_{2} / \mathrm{MeOH}$ (gradient elution from $97 / 3$ to $94 / 6$, v/v) as the eluent to give the title compound 154as a yellow solid (915 mg, 60\%). $\mathrm{R}_{\mathrm{f}}=0.24$ (silica, $\mathrm{CH}_{2} \mathrm{Cl}_{2} / \mathrm{MeOH}, 95 / 5$, v/v); m.p.: $96.5-99.2^{\circ} \mathrm{C} ;[\alpha]_{D}^{20}=+8.0$ (c 1.0, DMSO); IR (neat, $\mathrm{cm}^{-1}$ ): 3325.0, 3181.8, 2936.0, 2835.6, 1730.6, 1603.3, 1511.2, 1442.8; ${ }^{1} \mathrm{H}$ NMR (400 MHz, DMSO-d 6 ) $\delta 8.56(\mathrm{~s}, 1 \mathrm{H}), 8.34(\mathrm{~d}$, $J=7.5 \mathrm{~Hz}, 1 \mathrm{H}$ ), 7.71 (d, $J=8.9 \mathrm{~Hz}, 2 \mathrm{H}), 7.65$ (br s, 1H), 7.43 (br s, 1H), 7.27 (d, $J=6.9 \mathrm{~Hz}, 2 \mathrm{H}$ ), 7.25 (d, $J=6.9 \mathrm{~Hz}, 2 \mathrm{H}), 6.90-6.86$ (m, 4H), 6.82 (d, $J=8.9 \mathrm{~Hz}, 2 \mathrm{H}), 6.60$ (br s, 2H), $5.10-4.99$ (m, 2H), 4.97 (s, 2H), 4.78 (s, 2H), 4.42 (ddd, $J=9.6,7.5,5.4 \mathrm{~Hz}, 1 \mathrm{H}), 3.73$ (s, 6H), 3.21 (s, 3H), $2.42(\mathrm{t}, J=7.6 \mathrm{~Hz}, 2 \mathrm{H}), 2.13-1.90(\mathrm{~m}, 2 \mathrm{H}) ;{ }^{13} \mathrm{C}$ NMR (101 MHz, DMSO-d 6$) \delta$ 172.1, 172.0, 166.5, 162.9, 162.7, 159.1, 155.2, 151.0, 149.2, 145.9, 129.8, 129.7, 129.0, 128.0, 127.9, 121.4, 
120.8, 113.8, 111.0, 65.7, 65.3, 55.1, 54.8, 51.9, 38.8, 30.2, 25.8; HRMS (ESI) m/z: calcd for $\mathrm{C}_{36} \mathrm{H}_{39} \mathrm{~N}_{8} \mathrm{O}_{7}[\mathrm{M}+\mathrm{H}]^{+}$695.2936, found 695.2954.

\section{Bis(4-methoxybenzyl) （4-(((2-amino-4-)(((4-(4,4,5,5-tetramethyl-1,3,2-dioxaborolan-2-}

\section{yl)benzyl)oxy)carbonyl)amino)pteridin-6-yl)methyl)(methyl)amino)benzoyl)-L-glutamate}

(15). To a suspension of 15 (800 mg, $1.15 \mathrm{mmol}$ ) in anhydrous $\mathrm{CH}_{2} \mathrm{Cl}_{2}(25 \mathrm{~mL}$ ) was added DMAP (703 mg, $5.76 \mathrm{mmol}$ ) followed by DIPEA $(1.0 \mathrm{~mL}, 5.76 \mathrm{mmol})$. The mixture was cooled to $0{ }^{\circ} \mathrm{C}$ and a solution of $5 \mathbf{a}(1.71 \mathrm{~g}, 5.76 \mathrm{mmol})$ in $\mathrm{CH}_{2} \mathrm{Cl}_{2}(10 \mathrm{~mL})$ was added dropwise. The reaction was allowed to warm to $21{ }^{\circ} \mathrm{C}$ and stirred for $5 \mathrm{~h}$ under an $\mathrm{N}_{2}$ atmosphere. The mixture was then diluted with $\mathrm{CH}_{2} \mathrm{Cl}_{2}(100 \mathrm{~mL})$, washed with $1 \mathrm{M}$ aq. $\mathrm{HCl}(2 \times 75 \mathrm{~mL})$, sat. aq. $\mathrm{NaHCO}_{3}(2 \times 75$ $\mathrm{mL}$ ), and brine $(75 \mathrm{~mL})$. The organic layer was dried over $\mathrm{Na}_{2} \mathrm{SO}_{4}$, filtered and concentrated in vacuo. Purification of the residue by reversed-phase preparative HPLC afforded the title compound 15 as a yellow solid (800 mg, 73\%). m.p.: $>105.0$ (decomp.); $[\alpha]_{D}^{20}=+8.8$ (c 0.42, DMSO); IR (neat, $\mathrm{cm}^{-1}$ ): 3351.5, 3230.0, 2975.5, 2836.5, 1731.3, 1605.6, 1512.6, 1356.9; ${ }^{1} \mathrm{H}$ NMR (400 MHz, DMSO-d 6 ) 9.87 (s, 1H), 8.69 (s, 1H), 8.34 (d, $J=7.5 \mathrm{~Hz}, 1 \mathrm{H}), 7.72$ (d, $J=7.9 \mathrm{~Hz}, 4 \mathrm{H}), 7.47$ (d, $J$ = 7.9 Hz, 2H), $7.33-7.17(\mathrm{~m}, 6 \mathrm{H}), 6.91-6.85(\mathrm{~m}, 4 \mathrm{H}), 6.82(\mathrm{~d}, J=9.0 \mathrm{~Hz}, 2 \mathrm{H}), 5.26(\mathrm{~s}, 2 \mathrm{H})$, $5.06-4.98$ (m, 2H), 4.96 (s, 2H), 4.84 (s, 2H), 4.43 (ddd, $J=9.5,7.4,5.4 \mathrm{~Hz}, 1 \mathrm{H}), 3.72$ (s, 6H), 3.19 (s, 3H), 2.41 (t, $J=7.4 \mathrm{~Hz}, 2 \mathrm{H}), 2.13-1.91$ (m, 2H), 1.29 (s, 12H); ${ }^{13} \mathrm{C}$ NMR (101 MHz, DMSO- $\left.\mathrm{d}_{6}\right) \delta 172.1,172.0,166.5,162.0,159.1(2 \mathrm{C}), 157.8,155.1,151.1,150.7,150.3,148.0$, 139.3, 134.6, 129.8, 129.7, 129.0, 128.0, 127.9, 127.3, 121.0, 120.8, 113.8 (2C), 111.1, 83.7, 66.5, 65.7, 65.3, 55.1 (2C), 54.9, 51.9, 39.5, 30.2, 25.8, 24.7; HRMS (ESI) m/z: calcd for $\mathrm{C}_{50} \mathrm{H}_{56} \mathrm{BN}_{8} \mathrm{O}_{11}$ $[\mathrm{M}+\mathrm{H}]^{+}$955.4156, found 955.4191.

(S)-(4-(((2-Amino-6-(((4-((1,5-bis((4-methoxybenzyl)oxy)-1,5-dioxopentan-2yl)carbamoyl)phenyl)(methyl)amino)methyl)pteridin-4- 
yl)carbamoyl)oxy)methyl)phenyl)boronic acid (16). To a solution of 15 (0.70 g, $0.73 \mathrm{mmol})$ in a mixture of $\mathrm{CH}_{3} \mathrm{CN} / \mathrm{THF} / \mathrm{H}_{2} \mathrm{O}(200 \mathrm{~mL}, 2 / 1 / 1, \mathrm{v} / \mathrm{v})$ was added cc. $\mathrm{HCl}$ until $\mathrm{pH} \sim 2$. The reaction mixture was stirred at $21^{\circ} \mathrm{C}$ for $6 \mathrm{~h}$ followed by neutralization with sat. aq. $\mathrm{NaHCO}_{3}$ (approx. 50 $\mathrm{mL}$ ). After removal of organic solvents in vacuo, the formed precipitate was filtered off, washed with $\mathrm{H}_{2} \mathrm{O}$, and purified by reversed-phase preparative HPLC to afford the title compound $\mathbf{1 6}$ as a yellow solid (199 mg, 31\%). m.p.: $>147.8{ }^{\circ} \mathrm{C} ;[\alpha]_{D}^{20}=+8.3$ (c 0.99, DMSO); IR (neat, $\mathrm{cm}^{-1}$ ): 3362.3, 3230.6, 2954.1, 2836.7, 1732.0, 1628.9, 1605.5, 1512.4, 1198.7, 1170.9; ${ }^{1} \mathrm{H}$ NMR (400 MHz, DMSO-d 6 ) $\delta 9.10$ (br s, 1H), 8.64 (br s, 1H), 8.49 (s, 2H), 8.35 (d, $J=7.5$ Hz, 1H), 7.78 (d, $J=7.9 \mathrm{~Hz}, 2 \mathrm{H}), 7.71$ (d, $J=8.9 \mathrm{~Hz}, 2 \mathrm{H}), 7.40$ (d, $J=7.9 \mathrm{~Hz}, 2 \mathrm{H}), 7.37-7.10$ (m, 6H), 6.87 (d, $J$ $=8.7 \mathrm{~Hz}, 2 \mathrm{H}), 6.87$ (d, $J=8.6 \mathrm{~Hz}, 2 \mathrm{H}), 6.82(\mathrm{~d}, J=9.0 \mathrm{~Hz}, 1 \mathrm{H}), 5.21(\mathrm{~s}, 2 \mathrm{H}), 5.10-4.98(\mathrm{~m}, 2 \mathrm{H})$, 4.96 (s, 2H), 4.83 (s, 2H), 4.42 (ddd, $J=9.6,7.4,5.4 \mathrm{~Hz}, 1 \mathrm{H}$ ), 3.72 (s, 6H), 3.19 (s, 3H), 2.41 (t, $J$ = 7.6 Hz, 2H), $2.15-1.79$ (m, 2H); ${ }^{13} \mathrm{C}$ NMR (101 MHz, DMSO-d 6 ) $\delta$ 172.2, 172.0, 166.6, 162.1, 159.1 (2C), 157.8, 155.2, 151.1, 150.7, 150.3, 148.0, 132.7, 134.3, 129.9, 129.7, 129.1, 128.0, 127.9, 127.1, 121.0, 120.9, 113.8 (2C), 111.1, 66.7, 65.8, 65.4, 55.1 (2C), 54.9, 51.9, 39.35, 30.2, 25.8; HRMS (ESI) m/z: calcd for $\mathrm{C}_{44} \mathrm{H}_{46} \mathrm{BN}_{8} \mathrm{O}_{11}[\mathrm{M}+\mathrm{H}]^{+}$873.3374, found 873.3405 .

\section{(4-(((2-amino-4-(((4-Boronobenzyl)oxy)carbonyl)amino)pteridin-6-}

yl)methyl)(methyl)amino)benzoyl)-L-glutamic acid (17). A solution of 16 (150 mg, 0.17mmol)

in a mixture of $5 \%$ TFA in anhydrous $\mathrm{CH}_{2} \mathrm{Cl}_{2}(16 \mathrm{~mL})$ was stirred for 25 min under an $\mathrm{N}_{2}$ atmosphere at $21^{\circ} \mathrm{C}$. The crude mixture was then concentrated in vacuo and the residue purified by reversed-phase preparative HPLC to afford the title compound $\mathbf{1 7}$ as an yellow/orange solid (59 mg, 54\%). m.p.: $>200{ }^{\circ} \mathrm{C}$ (decomp.); $[\alpha]_{D}^{20}=+10.0$ (c 0.50, DMSO); IR (neat, $\mathrm{cm}^{-1}$ ): 3336.8, 3203.3, 2929.5, 1728.8, 1604.5, 1505.5, 1199.4, 1171.1; ${ }^{1} \mathrm{H}$ NMR (400 MHz, DMSO-d 6 ) $\delta 12.29$ (br s, 2H), 9.89 (s, 1H), 8.68 (s, 1H), 8.20 (d, $J=7.8 \mathrm{~Hz}, 1 \mathrm{H}$ ), 8.07 (s, 2H), 7.82 (d, $J=7.9 \mathrm{~Hz}$, 
2H), 7.73 (d, $J=8.9 \mathrm{~Hz}, 2 \mathrm{H}), 7.43$ (d, $J=7.9 \mathrm{~Hz}, 2 \mathrm{H}$ ), 7.28 (br s, 2H), 6.82 (d, $J=8.9 \mathrm{~Hz}, 2 \mathrm{H}$ ), 5.24 (s, 2H), 4.84 (s, 2H), 4.34 (ddd, $J=9.7,7.8,5.0 \mathrm{~Hz}, 1 \mathrm{H}$ ), 3.19 (s, 3H), 2.31 (t, $J=7.5 \mathrm{~Hz}$, 2H), $2.11-1.99$ (m, 1H), $1.99-1.79$ (m, 1H); ${ }^{13} \mathrm{C}$ NMR (101 MHz, DMSO-d 6 ) $\delta$ 173.9, 173.7, 166.3, 162.0, 157.8, 155.1, 151.0, 150.7, 150.3, 148.0, 137.7, 134.2, 129.0, 127.0, 121.3, 120.9, 111.1, 66.7, 54.9, 51.7, 39.0, 30.4, 26.0; HRMS (ESI) m/z: calcd for $\mathrm{C}_{28} \mathrm{H}_{28} \mathrm{BN}_{8} \mathrm{O} 9[\mathrm{M}-\mathrm{H}]^{-}$ 631.2078, found 631.2028.

4-(((Benzyloxy)carbonyl)amino)benzoic acid (19). To a solution of 4-methylaminobenzoic acid 18 (4.11 g, $29.9 \mathrm{mmol})$ and $\mathrm{NaHCO}_{3}(22.6 \mathrm{~g}, 269 \mathrm{mmol})$ in a mixture of $\mathrm{H}_{2} \mathrm{O} / \mathrm{THF}(100 \mathrm{~mL}$, $1 / 1, \mathrm{v} / \mathrm{v})$ was added benzyl chloroformate $(4.26 \mathrm{~mL}, 29.9 \mathrm{mmol})$ dropwise at $0{ }^{\circ} \mathrm{C}$. The reaction mixture was stirred for $4 \mathrm{~h}$ at $21{ }^{\circ} \mathrm{C}$ followed by addition of $20 \mathrm{~mL}$ of water. Then, the mixture was stirred for an additional $16 \mathrm{~h}$ followed by acidification with $1 \mathrm{M}$ aq. $\mathrm{HCl}$ to $\mathrm{pH} \sim 3$. Next, the precipitate was filtered off and dried in vacuo to afford 19 as a white solid (7.2 g, 89\%). m.p.: 213.0-217.0 ${ }^{\circ} \mathrm{C}$ (lit. ${ }^{72} 217{ }^{\circ} \mathrm{C}$, decomp.); IR (neat, $\mathrm{cm}^{-1}$ ): 3324.4, 2951.7, 2677.4, 2557.2, 1702.1, 1672.4, 1528.6, 1512.8, 1225.8, 1062.6; ${ }^{1} \mathrm{H}$ NMR (400 MHz, DMSO-d 6 ) $\delta 12.66$ (br s, 1H), 10.15 (s, 1H), 7.87 (d, $J=8.7 \mathrm{~Hz}, 2 \mathrm{H}), 7.58(\mathrm{~d}, J=8.7 \mathrm{~Hz}, 2 \mathrm{H}), 7.51-7.17$ (m, 5H), $5.17(\mathrm{~s}, 2 \mathrm{H}) ;{ }^{73}{ }^{13} \mathrm{C}$ NMR (101 MHz, DMSO-d 6 ) $\delta$ 167.0, 153.2, 143.3, 136.3, 130.5, 128.5, 128.2, 128.2, 124.5, 117.3, $66.1 .^{74}$

Dimethyl (4-(((benzyloxy)carbonyl)amino)benzoyl)-L-glutamate (20). To a suspension of 19 ( $2.90 \mathrm{~g}, 10.7 \mathrm{mmol}$ ) in anhydrous $\mathrm{CH}_{2} \mathrm{Cl}_{2}$ was added 1 drop of DMF followed by thionyl chloride (3.88 mL, $53.4 \mathrm{mmol}$ ) and the reaction mixture was refluxed for $24 \mathrm{~h}$ under an $\mathrm{N}_{2}$ atmosphere. Next, all volatiles were removed in vacuo to afford the acyl chloride as a pale yellow solid (3.1 g, $>95 \%)$ which was added to a stirred mixture of $\mathbf{9} \cdot \mathrm{HCl}(2.40 \mathrm{~g}, 11.3 \mathrm{mmol})$ and $\mathrm{Et}_{3} \mathrm{~N}$ in anhydrous $\mathrm{CH}_{2} \mathrm{Cl}_{2}(100 \mathrm{~mL})$ and an additional $2 \mathrm{~h}$ stirring was applied under an $\mathrm{N}_{2}$ atmosphere at $21^{\circ} \mathrm{C}$. The 
mixture was then diluted with EtOAc $(250 \mathrm{~mL})$, washed with $1 \mathrm{M}$ aq. $\mathrm{HCl}(2 \times 150 \mathrm{~mL})$, sat. aq. $\mathrm{NaHCO}_{3}(2 \times 150 \mathrm{~mL})$, and brine (200 mL), dried over $\mathrm{Na}_{2} \mathrm{SO}_{4}$, filtered, and concentrated in vacuo to afford the title compound 20 as a white solid (4.3 g, 97\%). m.p.: $121.7-124.0{ }^{\circ} \mathrm{C} ;[\alpha]_{D}^{20}=-16.2$ (c 1.0, MeOH); IR (neat, $\mathrm{cm}^{-1}$ ): 3378.3, 3297.8, 2952.4, 1730.5, 1627.7, 1526.8, 1227.4; ${ }^{1} \mathrm{H}$ NMR (400 MHz, DMSO-d $) \delta 10.07$ (s, 1H), 8.60 (d, $J=7.4 \mathrm{~Hz}, 1 \mathrm{H}), 7.83$ (d, $J=8.8 \mathrm{~Hz}, 2 \mathrm{H}$ ), 7.55 (d, $J=8.8 \mathrm{~Hz}, 2 \mathrm{H}), 7.50-7.26$ (m, 5H), 5.18 (s, 2H), 4.44 (ddd, $J=9.5,7.4,5.4 \mathrm{~Hz}, 1 \mathrm{H}$ ), 3.64 (s, 3H), 3.59 (s, 3H), 2.45 (t, $J=7.5 \mathrm{~Hz}, 2 \mathrm{H}), 2.22-1.83$ (m, 2H); ${ }^{13} \mathrm{C}$ NMR (101 MHz, DMSO-d 6 ) $\delta$ 172.7, 172.4, 166.1, 153.2, 142.1, 136.4, 128.5 (2C), 128.2, 128.1, 127.3, 117.2, 66.0, 51.9, 51.9, 51.4, 29.9, 25.7; HRMS (ESI) m/z: calcd for $\mathrm{C}_{22} \mathrm{H}_{25} \mathrm{~N}_{2} \mathrm{O}_{7}[\mathrm{M}+\mathrm{H}]^{+}$429.1656, found 429.1676 .

Dimethyl (4-aminobenzoyl)-L-glutamate hydrochloride $(21 \cdot \mathrm{HCl})$. A solution of $20(2.0 \mathrm{~g}, 4.8$ mmol) in anhydrous $\mathrm{MeOH}(100 \mathrm{~mL})$ was treated with $\mathrm{Pd} / \mathrm{C}(200 \mathrm{mg}, 10 \% \mathrm{w} / \mathrm{w})$. The mixture was stirred for $12 \mathrm{~h}$ under a $\mathrm{H}_{2}$ atmosphere at $21{ }^{\circ} \mathrm{C}$, then filtered through a path of Celite ${ }^{\circledR}$, concentrated in vacuo over silica gel and purified by flash column chromatography on silica gel using a mixture of EtOAc/Hep (2/1, v/v) as the eluent to give a clear oil corresponding to the free amine 21. Treatment with $2 \mathrm{M} \mathrm{HCl}$ in ether afforded the hydrochloride salt $\mathbf{2 1} \cdot \mathbf{H C l}$ as a white solid (1.3 g, 95\%). $\mathrm{R}_{\mathrm{f}}=0.38$ (free amine; EtOAc/Hep, 4/1, v/v); m.p.: $65.2-70.0^{\circ} \mathrm{C} ;[\alpha]_{D}^{20}=-17.8(\mathrm{c}$ 1.26, $\mathrm{H}_{2} \mathrm{O}$ ); IR (neat, $\mathrm{cm}^{-1}$ ): 3270.9, 2952.3, 2834.2, 2577.2, 1731.4, 1641.3, 1609.8, 1538.9, 1501.4, 1436.4, 1206.7, 1171.7; ${ }^{1} \mathrm{H}$ NMR (400 MHz, $\left.\mathrm{D}_{2} \mathrm{O}\right) \delta 7.78(\mathrm{~d}, \mathrm{~J}=8.5 \mathrm{~Hz}, 2 \mathrm{H}), 7.33(\mathrm{~d}, \mathrm{~J}=$ $8.5 \mathrm{~Hz}, 2 \mathrm{H}), 4.58(\mathrm{dd}, \mathrm{J}=9.4,5.2 \mathrm{~Hz}, 1 \mathrm{H}), 3.70(\mathrm{~s}, 3 \mathrm{H}), 3.56(\mathrm{~s}, 3 \mathrm{H}), 2.49(\mathrm{t}$, $\mathrm{J}=7.0 \mathrm{~Hz}, 2 \mathrm{H}), 2.35-2.20$ (m, 1H), 2.10 (ddt, $\mathrm{J}=14.2,9.4,6.9 \mathrm{~Hz}, 1 \mathrm{H}) ;{ }^{13} \mathrm{C}$ NMR $(101 \mathrm{MHz}$, $\left.\mathrm{D}_{2} \mathrm{O}\right) \delta 175.8,173.7,169.8,136.8,131.5,129.2,121.9,53.0,52.7,52.3,30.2,25.5$; HRMS (ESI) $\mathrm{m} / \mathrm{z}$ : calcd for $\mathrm{C}_{14} \mathrm{H}_{19} \mathrm{~N}_{2} \mathrm{O}_{5}[\mathrm{M}+\mathrm{H}]^{+}$295.1288, found 295.1297. 


\section{(S)-(4-(((4-((1,5-Dimethoxy-1,5-dioxopentan-2-}

yl)carbamoyl)phenyl)amino)methyl)phenyl) boronic acid (22). To a solution of $21 \cdot \mathrm{HCl}(0.80$

g, $2.42 \mathrm{mmol}$ ) in anhydrous $\mathrm{MeOH}$ was added (4-formylphenyl)boronic acid (0.55 g, $3.67 \mathrm{mmol}$ ) followed by portion-wise addition of $\mathrm{NaBH}_{3} \mathrm{CN}(0.80 \mathrm{~g}, 12.1 \mathrm{mmol})$. The reaction mixture was stirred for $12 \mathrm{~h}$ under an $\mathrm{N}_{2}$ atmosphere at $21^{\circ} \mathrm{C}$. Extra (4-formylphenyl)boronic acid (0.55 g, 3.67 mmol) was then added to the stirred mixture followed by an additional $24 \mathrm{~h}$ of stirring for completion of the reaction. Next, the crude mixture was concentrated in vacuo, redissolved in EtOAc (150mL), and washed with sat. aq. $\mathrm{NaHCO}_{3}(2 \times 150 \mathrm{~mL})$ and brine $(150 \mathrm{~mL})$. The organic phase was dried over $\mathrm{Na}_{2} \mathrm{SO}_{4}$, filtered, and concentrated in vacuo to afford a pale yellow solid. Purification by reversed-phase preparative HPLC afforded the title compound 22 as a white solid $(699 \mathrm{mg}, 67 \%) . \quad \mathrm{R}_{\mathrm{f}}=0.77$ (silica, $\mathrm{MeOH} / \mathrm{CH}_{2} \mathrm{Cl}_{2}, \quad 1 / 1$, v/v); m.p.: 84.1-88.2 ${ }^{\circ} \mathrm{C}$; $[\alpha]_{D}^{20}=-16.3$ (c 1.04, DMSO); IR (neat, $\mathrm{cm}^{-1}$ ): 3382.1, 2951.9, 1726.9, 1601.9, 1506.4, 1330.4; ${ }^{1} \mathrm{H}$ NMR (400 MHz, DMSO-d $) \delta 8.24(\mathrm{~d}, \mathrm{~J}=7.5 \mathrm{~Hz}, 1 \mathrm{H}), 7.98(\mathrm{~s}, 2 \mathrm{H}), 7.73(\mathrm{~d}, \mathrm{~J}=7.8 \mathrm{~Hz}, 2 \mathrm{H})$, $7.62(\mathrm{~d}, \mathrm{~J}=8.6 \mathrm{~Hz}, 2 \mathrm{H}), 7.30$ (d, J = 7.8 Hz, 2H), 6.84 (t, J = 6.0 Hz, 1H), 6.58 (d, J = 8.6 Hz, 2H), 4.38 (ddd, J = 9.5, 7.5, 5.6 Hz, 1H), 4.33 (d, J = 6.0 Hz, 2H), 3.61 (s, 3H), 3.57 (s, 3H), 2.41 (t, J $=7.4 \mathrm{~Hz}, 2 \mathrm{H}), 2.14-2.03(\mathrm{~m}, 1 \mathrm{H}), 2.02-1.86(\mathrm{~m}, 1 \mathrm{H}) ;{ }^{13} \mathrm{C}$ NMR $\left(101 \mathrm{MHz}, \mathrm{DMSO}-\mathrm{d}_{6}\right) \delta 172.8$, 172.7, 166.6, 151.4, 141.6, 134.2, 129.0, 126.2, 120.4, 111.1, 51.8, 51.7, 51.4, 46.0, 30.0, 25.8; HRMS (ESI) m/z: calcd for $\mathrm{C}_{21} \mathrm{H}_{26} \mathrm{BN}_{2} \mathrm{O}_{7}[\mathrm{M}+\mathrm{H}]^{+}$429.1828, found 429.1850 .

\section{(S)-(4-((((2,4-Diaminopteridin-6-yl)methyl)(4-((1,5-dimethoxy-1,5-dioxopentan-2-}

yl)carbamoyl)phenyl)amino)methyl)phenyl)boronic acid (24). A solution of 22 (461 mg, 1.08 mmol) and 6-(bromomethyl)pteridine-2,4-diamine hydrobromide $23 \cdot \mathrm{HBr}(515 \mathrm{mg}, 1.38 \mathrm{mmol})$ in anhydrous DMA (4.85 mL) was stirred for three days under an $\mathrm{N}_{2}$ atmosphere at $55{ }^{\circ} \mathrm{C}$. Then, $\mathrm{Et}_{3} \mathrm{~N}\left(79 \mu \mathrm{L}, 3.21 \mathrm{mmol}\right.$ ) was added to the mixture followed by addition of $\mathrm{H}_{2} \mathrm{O}$ (approx. $30 \mathrm{~mL}$ ). 
The orange precipitate was filtered off and purified by reversed-phase preparative HPLC to afford 24 as a yellow solid (279 mg, 43\%). $\mathrm{R}_{\mathrm{f}}=0.47$ (silica, $\mathrm{CH}_{2} \mathrm{Cl}_{2} / \mathrm{MeOH}, 85 / 15$, v/v); m.p.: $>180{ }^{\circ} \mathrm{C}$ (decomp.); $[\alpha]_{D}^{20}=+1.75$ (c 0.57, DMSO-d 6 ); IR (neat, $\mathrm{cm}^{-1}$ ): 3485.2, 3327.3, 3169.7, 2952.1, 1727.2, 1625.3, 1602.2, 1201.7; ${ }^{1} \mathrm{H}$ NMR (400 MHz, DMSO-d 6 ) $\delta 8.64$ (s, $1 \mathrm{H}$ ), 8.31 (d, $J=7.5$ Hz, 1H), 7.99 (s, 2H), 7.75 (d, $J=8.0 \mathrm{~Hz}, 2 \mathrm{H}), 7.72-7.60$ (m, 3H), 7.47 (br s, 1H), 7.23 (d, $J=$ $8.0 \mathrm{~Hz}, 2 \mathrm{H}$ ), 6.82 (d, $J=9.1 \mathrm{~Hz}, 2 \mathrm{H}), 6.63$ (br s, 2H), 4.93 (s, 2H), 4.89 (s, 2H), 4.38 (ddd, $J$ = 9.6,

7.5, $5.3 \mathrm{~Hz}, 1 \mathrm{H}), 3.61$ (s, 3H), 3.57 (s, 3H), 2.41 (t, $J=7.5 \mathrm{~Hz}, 2 \mathrm{H}), 2.17-1.79$ (m, 2H); ${ }^{13} \mathrm{C}$ NMR (101 MHz, DMSO-d 6 ) $\delta$ 172.72, 172.54, 166.38, 162.83, 162.71, 155.18, 150.37, 149.36, 145.92, 140.38, 134.39, 128.93, 125.66, 121.41, 121.10, 111.48, 54.47, 53.98, 51.82, 51.71, 51.35, 29.92, 25.77; HRMS (ESI) m/z: calcd for $\mathrm{C}_{28} \mathrm{H}_{32} \mathrm{BN}_{8} \mathrm{O}_{7}[\mathrm{M}+\mathrm{H}]^{+}$603.2482, found 603.2508.

(4-((4-Boronobenzyl)((2,4-diaminopteridin-6-yl)methyl)amino)benzoyl)-L-glutamic acid (25). A solution of 24 (46 mg, $76 \mu \mathrm{mol}$ ) in $1 \mathrm{M}$ aq. $\mathrm{NaOH}(2 \mathrm{~mL})$ was stirred for $5 \mathrm{~min}$ at $21^{\circ} \mathrm{C}$. The crude was directly purified by reversed-phase preparative HPLC to afford the title compound 25 as a yellow solid (17 mg, 40\%). m.p.: $>245{ }^{\circ} \mathrm{C}$ (decomp.); $[\alpha]_{D}^{20}=+7.8$ (c 0.63, DMSO); IR (neat, $\mathrm{cm}^{-1}$ ): 3336.5, 3089.8, 1633.5, 602.7, 1502.8, 1394.2, 1364.9, 1337.0, 1202.5; ${ }^{1} \mathrm{H}$ NMR (400 MHz, DMSO-d $\left.\mathrm{d}_{6}\right) \delta 8.63(\mathrm{~s}, 1 \mathrm{H}), 8.08(\mathrm{~d}, J=7.3 \mathrm{~Hz}, 1 \mathrm{H}), 8.01(\mathrm{~s}, 2 \mathrm{H}), 7.73(\mathrm{~d}$, $J=7.9 \mathrm{~Hz}, 2 \mathrm{H}$ ), $7.69-7.55$ (m, 3H), 7.46 (br s, 1H), 7.22 (d, $J=7.9 \mathrm{~Hz}, 2 \mathrm{H}), 6.81$ (d, $J=8.9 \mathrm{~Hz}$, 2H), 6.61 (br s, 2H), 4.91 (s, 2H), 4.88 (s, 2H), 4.32 (ddd, $J=9.7,7.9,5.1 \mathrm{~Hz}, 1 \mathrm{H}), 2.3$ (t, $J=7.5,2 \mathrm{H}), 2.02-1.78(\mathrm{~m}, 2 \mathrm{H}) ;{ }^{13} \mathrm{C}$ NMR (101 MHz, DMSO-d 6$) \delta 174.0,173.7,166.2,162.9$, 162.7, 155.2, 150.3, 149.4, 145.9, 140.4, 134.4, 128.8, 125.7, 121.5, 121.4, 111.5, 54.4, 54.0, 51.8, 30.6, 26.2; HRMS (ESI) m/z: calcd for $\mathrm{C}_{26} \mathrm{H}_{28} \mathrm{BN}_{8} \mathrm{O}_{7}[\mathrm{M}+\mathrm{H}]^{+}$575.2169, found 575.2187.

\section{Physicochemical and pharmacokinetic in vitro assays}


Activation of prodrugs under oxidative conditions. To a mixture of DMSO $(150 \mu \mathrm{L})$ and aq. PBS buffer $(650 \mu \mathrm{L}, \mathrm{pH} 7.4)$ in a microcentrifuge tube $(1.5 \mathrm{~mL})$ placed in a thermomixer at $37^{\circ} \mathrm{C}$ was added a solution of prodrug (50 $\mu \mathrm{L}, 1 \mathrm{mM}$ in DMSO) followed by addition of internal standard solution (diclofenac, $50 \mu \mathrm{L}, 1 \mathrm{mM}$ in DMSO). The assay was initiated by addition of a solution of $\mathrm{H}_{2} \mathrm{O}_{2}$ in PBS (50 $\left.\mu \mathrm{L}, 10 \mathrm{mM}\right)$ followed by vortex mixing. The resulting mixture was incubated at $37^{\circ} \mathrm{C}$ in an Eppendorf Thermomixer C (1.5 mL, $\left.1000 \mathrm{rpm}\right)$ and samples were taken after 5, 15, 30, 60, $90 \mathrm{~min}$ and 2, 3, and $4 \mathrm{~h}$. Analysis of the percentage of remaining compound was performed using RP-UPLC-UV $(\lambda=306 \mathrm{~nm})$. Further data points were collected for compounds 24 and 25 , including 16, 24 and $48 \mathrm{~h}$. A control experiment (no $\mathrm{H}_{2} \mathrm{O}_{2}$ addition but PBS) was performed in parallel. Every prodrug activation assay was carried out in triplicates.

Activation of prodrugs under different $\mathrm{H}_{2} \mathrm{O}_{2}$ concentrations. To aq. PBS buffer ( $\left.750 \mu \mathrm{L}, \mathrm{pH} 7.4\right)$ was added a solution of prodrug 17 or $\mathbf{2 5}$ (100 $\mu \mathrm{L}, 1 \mathrm{mM}$ in DMSO) followed by addition of internal standard solution (diclofenac, $100 \mu \mathrm{L}, 1 \mathrm{mM}$ in DMSO). The assay was initiated by addition of a solution of $\mathrm{H}_{2} \mathrm{O}_{2}$ in PBS (50 $\mu \mathrm{L}, 10-5-1-0.5-0.25 \mathrm{mM}$ ) followed by vortex mixing. The resulting mixture was incubated at $37^{\circ} \mathrm{C}$ in a Eppendorf Thermomixer $\mathrm{C}(1.5 \mathrm{~mL}$, $1000 \mathrm{rpm}$ ) and samples were taken after 5, 15, 30, 60, $90 \mathrm{~min}$ and 2, 4, $24 \mathrm{~h} \mathrm{(48} \mathrm{h} \mathrm{for} \mathrm{compound}$ 25). Analysis of the percentage of remaining compound was performed using RP-UPLC-UV ( $\lambda=$ $306 \mathrm{~nm}$ ). A control experiment (no $\mathrm{H}_{2} \mathrm{O}_{2}$ addition but PBS) was performed in parallel. Every prodrug activation assay was carried out in triplicates.

Kinetic solubility. The kinetic solubility of prodrugs 11, 12, 13, 17, 24, and 25 was determined in a $1 \%$ DMSO in PBS solution at a concentration of $100 \mu \mathrm{M}$. A solution of test compound (10 $\mu \mathrm{L}, 10 \mathrm{mM}$ ) was added to an microcentrifuge tube containing PBS (990 $\mu \mathrm{L}, \mathrm{pH} 7.4)$, and the mixture was incubated at $37^{\circ} \mathrm{C}$ for 20 hours in a Eppendorf Thermomixer C (1.5 mL, $\left.1000 \mathrm{rpm}\right)$. 
After $20 \mathrm{~h}$ incubation, the samples were centrifuged at $5000 \mathrm{rpm}\left(37^{\circ} \mathrm{C}, 30 \mathrm{~min}\right)$ to pellet insoluble material. Aliquots $(250 \mu \mathrm{L})$ of the supernatant were diluted in PBS $(250 \mu \mathrm{L})$ and the concentration of dissolved compound was quantified by RP-UPLC-UV ( $\lambda=306 \mathrm{~nm})$ analysis. Solubility determinations were performed in triplicates.

Chemical Stability $p H$ 7.4. The chemical stability at $\mathrm{pH} 7.4$ of compounds $\mathbf{1 7}$ and $\mathbf{2 5}$ was assessed using diclofenac as an internal standard. To $490 \mu \mathrm{L}$ of a pre-warmed solution of $20 \mu \mathrm{M}$ diclofenac in PBS (0.1\% DMSO) was added $10 \mu \mathrm{L}$ of a $1 \mathrm{mM}$ DMSO solution of compound 17 and 25 (in triplicates) and RP-UPLC-UV ( $\lambda=306 \mathrm{~nm}$ ) analysis was performed after $30 \mathrm{~min}, 1 \mathrm{~h}, 2$ h, 4 h, 8 h, 24 h, and 48 h.

Simulated gastric and intestinal fluid stability. Simulated gastric fluid (SGF) was generated by preparing a solution of sodium chloride $(0.20 \mathrm{~g})$, concentrated $\mathrm{HCl}(0.70 \mathrm{~mL})$, and pepsin (Sigma, P-7000, $0.32 \mathrm{~g}$ ) in deionized water $(95 \mathrm{~mL})$ up to a $100 \mathrm{~mL}$ of final volume. Simulated instestinal fluid (SIF) was generated by preparing a solution of monobasic potassium phosphate $\left(\mathrm{KH}_{2} \mathrm{PO}_{4}\right.$, $0.68 \mathrm{~g}$ ), $0.1 \mathrm{~N}$ aqueous sodium hydroxide (38 mL), and pancreatin (Sigma, P-1625, $1.0 \mathrm{~g}$ ) in deionized water up to $100 \mathrm{~mL}$ of final volume. The $\mathrm{pH}$ of the solution was adjusted to 7.5 by addition of $1 \mathrm{~N}$ aqueous sodium hydroxide. ${ }^{75}$ To $990 \mu \mathrm{L}$ of SGF or SIF was added a solution of prodrug 17 or $25\left(10 \mu \mathrm{L}, 10 \mathrm{mM}\right.$ in DMSO). The resulting mixture was incubated at $37^{\circ} \mathrm{C}$ in a Eppendorf Thermomixer C (1.5 mL, $1000 \mathrm{rpm})$ and samples were taken (90 $\mu \mathrm{L})$ after 0, 1, 2, 4, and $24 \mathrm{~h}$. Diclofenac (10 $\mu \mathrm{L}, 1 \mathrm{mM}$ in DMSO) was added to the taken samples as internal standard. Analysis of the percentage of remaining compound was performed using RP-UPLC-UV ( $\lambda=306$ nm). A negative control experiment (no pepsin or pancreatin addition) was performed in parallel. Every assay was carried out in triplicates. 
Human and mouse plasma stability. $2 \mathrm{~mL}$ of lyophilized plasma (Sigma, P9523 for human and P9275 for mouse plasma) were dissolved in $2 \mathrm{~mL}$ of milli-Q water. To an microcentrifuge tube containing $240 \mu \mathrm{L}$ of pre-warmed PBS $\left(37^{\circ} \mathrm{C}\right.$ ) was added $250 \mu \mathrm{L}$ of plasma. The mixture was shaken at $300 \mathrm{rpm}$ in an Eppendorf Thermomixer C (1.5 mL, $300 \mathrm{rpm})$ for 10 min before the assay was started. A solution of test compound 17 and 25 in DMSO $(1 \mathrm{mM}, 10 \mu \mathrm{L})$ was added to the pre-warmed PBS/plasma mixture to a final concentration of $20 \mu \mathrm{M}$. Samples $(50 \mu \mathrm{L})$ were taken after $30 \mathrm{~min}, 1 \mathrm{~h}, 2 \mathrm{~h}, 4 \mathrm{~h}, 8 \mathrm{~h}, 24 \mathrm{~h}$ and $48 \mathrm{~h}$ and added to $150 \mu \mathrm{L}$ of ice-cold $\mathrm{MeOH}$ containing an internal standard (diclofenac, $10 \mu \mathrm{M}$ ). Procaine and dilizatem were used as positive controls for human and mouse plasma stability, respectively. The half-lives $\left(\mathrm{t}_{1 / 2}\right)$ was determined using GraphPad Prism 6 software and calculated with the slope of the linear region of the plotted logarithm of remaining compound against time, assuming first order kinetics.

Human and mice microsomal stability. The in vitro microsomal metabolism of compounds $\mathbf{1 7}$ and 25 was evaluated in isolated liver microsomes (pooled, from CD-1 male mouse and from human male) at a concentration of $10 \mu \mathrm{M}$. A solution of liver microsomes (10 mg/mL, $25 \mu \mathrm{L})$ was added to an microcentrifuge tube containing $425 \mu \mathrm{L}$ of PBS at $37^{\circ} \mathrm{C}$ in an Eppendorf Thermomixer C (1.5 mL, $1000 \mathrm{rpm})$ and the mixture was shaken for $10 \mathrm{~min}$ before the actual assay was started. Then, a DMSO solution of test compound $(5 \mu \mathrm{L}, 1 \mathrm{mM})$ was added followed by an aq. solution of NADPH $(25 \mu \mathrm{L})$ for initiation of the experiment. A negative (no NADPH) and a positive control experiments (verapamil and diphenhydramine for human and mouse, respectively) were carried out in parallel. Aliquots ( $50 \mu \mathrm{L}$ ) were removed after 0 min, 5 min, 10 min, 15 min, 30 min, 45 min, and 60 min (additional $120 \mathrm{~min}$ and $240 \mathrm{~min}$ time points for the mice study) and quenched immediately with $50 \mu \mathrm{L}$ of ice-cold MeCN containing an internal standard (diclofenac $10 \mu \mathrm{M}$ ). 
Samples were analysed by RP-UPLC-UV and half-lives calculated plotting the Ln [C] versus time, assuming first order kinetics using GraphPad Prism 6.

\section{Cellular Assays}

Materials. Dulbecco’s Phosphate buffer (D-PBS) was purchased from Sigma Aldrich (D8662, pH 7.4). DMEM (D5976, Sigma Aldrich) and RPMI (R8758, Sigma Aldrich) were supplemented with $10 \%$ foetal bovine serum (FBS, heat-inactivated, Fisher Scientific), penicillin at 100 units $/ \mathrm{mL}$, and streptomycin at $100 \mathrm{mg} / \mathrm{mL}$ (all purchased from Sigma Aldrich). The CellTiter $96{ }^{\circledR}$ AQueous Non-Radioactive Cell Proliferation Assay was purchased from Promega (MTS, G5421).

Cell Culture. The human breast cancer MCF-7 (Sigma) and human large cell lung cancer NCIH460 (ATTC) cell lines were cultured in a humidified, $5 \% \mathrm{CO}_{2}$ atmosphere at $37{ }^{\circ} \mathrm{C}$ in Dulbecco's Modified Eaglés Medium (DMEM) (Sigma) or Roswell Park Memorial Institute medium (RPMI) 1640 (Sigma) supplemented with 10\% foetal bovine serum (FBS, heat-inactivated, Fisher Scientific) and 1\% penicillin/streptomycin. Both cell lines were subcultured every 2-3 days.

Pre-activation of compounds with $\mathrm{H}_{2} \mathrm{O}_{2}$. A $125 \mu \mathrm{M}$ solution of tested compound was prepared in a $1.25 \mathrm{mM} \mathrm{H}_{2} \mathrm{O}_{2}$ in DMSO:PBS (1:1), placed in an microcentrifuge tube and shaken at $21{ }^{\circ} \mathrm{C}$ for $24 \mathrm{~h}$ at $1000 \mathrm{rpm}$ in an Eppendorf Thermomixer C $(1.5 \mathrm{~mL})$. The activation was followed by RP-UPLC-MS ( $\lambda=306 \mathrm{~nm}$ ) after $0 \mathrm{~min}, 15 \mathrm{~min}, 1 \mathrm{~h}, 4 \mathrm{~h}$, and $24 \mathrm{~h}$. A negative control consisting of a $125 \mu \mathrm{M}$ solution of compound in a mixture of DMSO:PBS (1:1) without $\mathrm{H}_{2} \mathrm{O}_{2}$ was run in parallel to the activation assay under the same conditions. 
Evaluation of cell viability. The 3-(4,5-dimethylthiazol-2-yl)-5-(3-carboxymethoxyphenyl)-2(4-sulfophenyl)-2H-te-trazolium (MTS) assay (Promega Biotech AB, Stockholm, Sweden ) was used to determine the in vitro antiproliferative effect of the compounds. This assay is based on the principle that cells have the ability to reduce MTS tetrazolium, while, when dead, they lose this ability. MCF-7 and NCI-H460 cells were cultured in 96-well plates at an initial density of $10^{4}$ cells/well (MCF-7) or 7x10 cells/well (NCI-H460) in their respective growth medium. After 24 $\mathrm{h}$ incubation to allow cell attachment, the medium was removed and the cells were incubated in the presence or absence of pre-activated compounds at different concentrations. After $48 \mathrm{~h}$ incubation time, the MTS reagent was added to each well. The cells were further incubated for a period of time between $30-60$ min at $37^{\circ} \mathrm{C}$ until colorimetric reaction was developed within the linear range and the absorbance of the samples was measured at $490 \mathrm{~nm}$ using a 96-well plate spectrophotometer (Victor 3 plate reader with Wallac 1420 Workstation vs 3.0 software).

A control was used for each tested compound, where cells were incubated with DMEM or RPMI containing the equivalent concentration of DMSO (maximum of $0.4 \% \mathrm{v} / \mathrm{v}$ ). Each concentration of tested compounds was done in triplicates. The final concentration of $\mathrm{H}_{2} \mathrm{O}_{2}$ in each well was always $<10 \mu \mathrm{M}$ (non-cytotoxic concentration in MCF-7 and NCI-H460 cell lines, determined with the described assay). The $\mathrm{IC}_{50}$ values were calculated using GraphPad Prism v6.0 (California, USA) as the concentration of the compounds required to cause $50 \%$ response compared to cells exposed to controls using a non-linear dose-response regression.

\section{Collagen type-II-induced arthritis in vivo efficacy and preliminary toxicity assay}

Animals: DBA/1J mice (male, 8-9 weeks) were obtained from Janvier, France. The mice were maintained in the animal facility at Redoxis, Medicon Village, Lund, Sweden, where they were 
acclimatized for approximately one week before initiation of the experiment. All animal experiments were approved by the local animal ethic committee Malmö/Lund, Sweden, under the license N165-15.

Induction of disease: collagen induced arthritis (CIA) was induced by intradermal immunization with $100 \mu \mathrm{g}$ of chicken type-II collagen (CII, Chondrex) in Complete Freund's Adjuvant (CFA, Difco) on day -1 via subcutaneous injection approximately $0.5 \mathrm{~cm}$ from the base of the tail. On day 21 a boost injection was administered in the same way with $50 \mu$ C CII. One week after the second immunization, onset of disease started to be observed (day 26).

Anti-arthritic effect of test compounds and health evaluation: mice were randomly divided in 5 groups ( $\mathrm{n}=8$ per group): group I (vehicle), group II (MTX, Sigma Aldrich, $7.0 \mathrm{mg} / \mathrm{kg}$, i.p.), group III (AMT, Enzo Life Sciences, 6.8 mg/kg, i.p.), group IV (17, 9.7 mg/kg, i.p.), group V (25, 8.8 $\mathrm{mg} / \mathrm{kg}$, i.p.). Vehicle or test compound (2\% DMSO in PBS, Life Technologies, injection volume $370 \mu \mathrm{L}$ ) were dosed daily by intraperitoneal injections for 14 days, starting at onset of disease (day 27). Disease was evaluated three times per week in a blinded fashion, starting at day 18 until the end of the experiment (day 40). A macroscopic scoring system of the four limbs ranging from 0 to 15 (1 point per swollen toe, 1 point per swollen foot knuckle, and 5 points for swollen ankle) was used, meaning a maximal score of 60 per mice. For humane and ethical reasons and restrictions, mice with scores exceeding 45 were euthanized. The general health of mice was evaluated three times per week after disease induction. As an indicator of general health, animal body weight was used.

\section{AUTHOR INFORMATION}

\section{Corresponding Author}


Phone: +45 452521 31. E-mail: mhc@kemi.dtu.dk

\section{Author Contributions}

JPC and VP performed experiments. JPC, JB, CAH, VP, AEH, TLA and MHC designed the study, analyzed data and wrote the manuscript. All authors have approved the final version of the manuscript.

\section{ACKNOWLEDGMENT}

\section{Funding Sources}

We are grateful for financial support from the Independent Research Fund Denmark (grant no. 7017-00026) and the Technical University of Denmark (PoC funding and a PhD scholarship for JPC).

\section{ABBREVIATIONS}

AMT, aminopterin; ADMET, absorption, distribution, metabolism, excretion, and toxicity; CIA, collagen-induced arthritis; CLint, intrinsic clearance; DMARD; disease modifying anti-rheumatic drug; LD-MTX, low-dose methotrexate; ROS, reactive oxygen species; RP-UPLC-MS, reversedphase ultra-performance liquid chromatography; MTX, methotrexate; PBS, phosphate buffered saline; RA, rheumatoid arthritis; SEM, standard error mean; TLC, thin layer chromatography.

\section{ASSOCIATED CONTENT}

Supporting Information. Hydrogen peroxide prodrug activation, cell viability, chemical, SGF, SIF, plasma, and metabolic stabilities assays and assigned NMR spectra of synthesized compounds, as well as a molecular formula strings file. This material is available free of charge via the Internet at http://pubs.acs.org. 


\section{REFERENCES}

(1) Koch, A. E. The Pathogenesis of Rheumatoid Arthritis. Am. J. Orthop. (Belle Mead. NJ). 2007, 36, 5-8.

(2) Smolen, J. S.; Aletaha, D.; McInnes, I. B. Rheumatoid Arthritis. Lancet 2016, 388 (10055), 2023-2038.

(3) Gubner, R. Therapeutic Suppression of Tissue Reactivity. I. Comparison of the Effects of Cortisone and Aminopterin. Am. J. Med. Sci. 1951, 221 (2), 169-175.

(4) Gubner, R.; August, S.; Ginsberg, V. Therapeutic Suppression of Tissue Reactivity. II. Effects of Aminopterin in Rheumatoid Arthritis and Psoriasis. Am. J. Med. Sci. 1951, 221 (2), 176-182.

(5) Rees, R. B.; Bennett, J. H.; Hamlin, E.; Maibach, H. Aminopterin for Psoriasis: A Decade’s Observation. Arch. Dermatol. 1964, 90 (6), 544-552.

(6) Sacks, M. S.; Bradford, G. T.; Schoenbach, E. B. The Response of Acute Leukemia to the Administration of the Folic Acid Antagonists, Aminopterin and Amethopterin: Report of 14 Cases. Ann. Intern. Med. 1950, 32 (1), 80-115.

(7) Mills, S. D.; Stickney, J. M.; Hagedorn, A. B. Observations on Acute Leukemia in Children Treated with 4-Aminopteroylglutamic Acid. Pediatrics 1950, 5 (1), 52-56.

(8) Meyer, L. M.; Fink, H.; Sawitsky, A.; Rowen, M.; Ritz, N. D. Aminopterin (a Folic Acid Antagonist) in the Treatment of Leukemia. Am. J. Clin. Pathol. 1949, 19 (2), 119-126.

(9) Meyer, L. M.; Newman, A. Treatment of Leukemia with Aminopterin. Am. J. Med. 1951, $10(4), 452-458$.

(10) Goldin, A.; Venditti, J. M.; Humphreys, S. R.; Dennis, D.; Mantel, N.; Greenhouse, S. W. A Quantitative Comparison of the Antileukemic Effectiveness of Two Folic Acid 
Antagonists in Mice. JNCI J. Natl. Cancer Inst. 1955, 15 (6), 1657-1664.

(11) Weinblatt, M. E. Methotrexate in Rheumatoid Arthritis: A Quarter Century of Development. Trans. Am. Clin. Climatol. Assoc. 2013, 124, 16-25.

(12) Ćalasan, M. B.; Thurlings, R. M.; Wulffraat, N. M.; Prakken, B. J. Translational Medicine from Bedside to Bench and Back Again: Methotrexate Revisited. Int. J. Clin. Rheumtol. 2013, 8 (2), 291-306.

(13) Cronstein, B. N. Low-Dose Methotrexate: A Mainstay in the Treatment of Rheumatoid Arthritis. Rev. Pharmacol. 2005, 57 (2), 163-172.

(14) Bonafede, M.; Joseph, G. J.; Shah, N.; Princic, N.; Harrison, D. J. Cost of Tumor Necrosis Factor Blockers per Patient with Rheumatoid Arthritis in a Multistate Medicaid Population. Clin. Outcomes Res. 2014, 6, 381-388.

(15) Tian, H.; Cronstein, B. N. Understanding the Mechanisms of Action of Methotrexate: Implications for the Treatment of Rheumatoid Arthritis. Bull. NYU Hosp. Jt. Dis. 2007, 65 (3), 168-173.

(16) Alarcón, G. S.; Tracy, I. C.; Blackburn Jr., W. D. Methotrexate in Rheumatoid Arthritis. Toxic Effects as the Major Factor in Limiting Long-Term Treatment. Arthritis Rheum. 1989, 32 (6), 671-676.

(17) Hashkes, P. J.; Balistreri, W. F.; Bove, K. E.; Ballard, E. T.; Passo, M. H. The Long-Term Effect of Methotrexate Therapy on the Liver in Patients with Juvenile Rheumatoid Arthritis. Arthritis Rheum. 1997, 40 (12), 2226-2234.

(18) Khanna, D.; Park, G. S.; Paulus, H. E.; Simpson, K. M.; Elashoff, D.; Cohen, S. B.; Emery, P.; Dorrier, C.; Furst, D. E. Reduction of the Efficacy of Methotrexate by the Use of Folic Acid: Post Hoc Analysis from Two Randomized Controlled Studies. Arthritis Rheum 2005, 
52 (10), 3030-3038.

(19) Rautio, J.; Kumpulainen, H.; Heimbach, T.; Oliyai, R.; Oh, D.; Järvinen, T.; Savolainen, J. Prodrugs: Design and Clinical Applications. Nat. Rev. Drug Discov. 2008, 7, 255-270.

(20) Huttunen, K. M.; Raunio, H.; Rautio, J. Prodrugs - from Serendipity to Rational Design. Pharmacol. Rev. 2011, 63 (3), 750-771.

(21) Zawilska, J. B.; Wojcieszak, J.; Olejniczak, A. B. Prodrugs: A Challenge for the Drug Development. Pharmacol. Reports 2013, 65, 1-14.

(22) Khan, Z. A.; Tripathi, R.; Mishra, B. Methotrexate: A Detailed Review on Drug Delivery and Clinical Aspects. Expert Opin. Drug Deliv. 2012, 9 (2), 151-169.

(23) Abolmaali, S. S.; Tamaddon, A. M.; Dinarvand, R. A Review of Therapeutic Challenges and Achievements of Methotrexate Delivery Systems for Treatment of Cancer and Rheumatoid Arthritis. Cancer Chemother. Pharmacol. 2013, 71 (5), 1115-1130.

(24) Wunder, A.; Müller-Ladner, U.; Stelzer, E. H. K.; Funk, J.; Neumann, E.; Stehle, G.; Pap, T.; Sinn, H.; Gay, S.; Fiehn, C. Albumin-Based Drug Delivery as Novel Therapeutic Approach for Rheumatoid Arthritis. J. Immunol. 2003, 170 (9), 4793-4801.

(25) Fiehn, C.; Kratz, F.; Sass, G.; Müller-Ladner, U.; Neumann, E. Targeted Drug Delivery by in Vivo Coupling to Endogenous Albumin: An Albumin-Binding Prodrug of Methotrexate (MTX) Is Better than MTX in the Treatment of Murine Collagen-Induced Arthritis. Ann. Rheum. Dis. 2008, 67 (8), 1188-1191.

(26) Homma, A.; Sato, H.; Okamachi, A.; Emura, T.; Ishizawa, T.; Kato, T.; Matsuura, T.; Sato, S.; Tamura, T.; Higuchi, Y.; Watanabe, T.; Kitamura, H.; Asanuma, K.; Yamazaki, T.; Ikemi, M.; Kitagawa, H.; Morikawa, T.; Ikeya, H.; Maeda, K.; Takahashi, K.; Nohmi, K.; Izutani, N.; Kanda, M.; Suzuki, R. Novel Hyaluronic Acid-Methotrexate Conjugates for 
Osteoarthritis Treatment. Bioorganic Med. Chem. 2009, 17 (3), 4647-4656.

(27) Tamura, T.; Higuchi, Y.; Kitamura, H.; Murao, N.; Saitoh, R.; Morikawa, T.; Sato, H. Novel Hyaluronic Acid-methotrexate Conjugate Suppresses Joint Inflammation in the Rat Knee: Efficacy and Safety Evaluation in Two Rat Arthritis Models. Arthritis Res. Ther. 2016, 18:79, 1-11.

(28) Homma, A.; Sato, H.; Tamura, T.; Okamachi, A.; Emura, T.; Ishizawa, T.; Kato, T.; Matsuura, T.; Sato, S.; Higuchi, Y.; Watanabe, T.; Kitamura, H.; Asanuma, K.; Yamazaki, T.; Ikemi, M.; Kitagawa, H.; Morikawa, T.; Ikeya, H.; Maeda, K.; Takahashi, K.; Nohmi, K.; Izutani, N.; Kanda, M.; Suzuki, R. Synthesis and Optimization of Hyaluronic AcidMethotrexate Conjugates to Maximize Benefit in the Treatment of Osteoarthritis. Bioorganic Med. Chem. 2010, 18 (3), 1062-1075.

(29) Williams, a S.; Camilleri, J. P.; Amos, N.; Williams, B. D. Differential Effects of Methotrexate and Liposomally Conjugated Methotrexate in Rat Adjuvant-Induced Arthritis. Clin. Exp. Immunol. 1995, 102 (3), 560-565.

(30) Hong, M. S.; Lim, S. J.; Lee, M. K.; Kim, Y. B.; Kim, C. K. Prolonged Blood Circulation of Methotrexate by Modulation of Liposomal Composition. Drug Deliv. 2001, 8 (4), 231237.

(31) Liang, L. S.; Jackson, J.; Min, W.; Risovic, V.; Wasan, K. M.; Burt, H. M. Methotrexate Loaded Poly(L-Lactic Acid) Microspheres for Intra-Articular Delivery of Methotrexate to the Joint. J. Pharm. Sci. 2004, 93 (4), 943-956.

(32) Miao, B.; Song, C.; Ma, G. Injectable Thermosensitive Hydrogels for Intra-Articular Delivery of Methotrexate. J. Appl. Polym. Sci. 2011, 22, 2139-2145.

(33) Kratz, F. Albumin as a Drug Carrier: Design of Prodrugs, Drug Conjugates and 
Nanoparticles. J. Control. Release 2008, 132 (3), 171-183.

(34) Mittal, M.; Siddiqui, M. R.; Tran, K.; Reddy, S. P.; Malik, A. B. Reactive Oxygen Species in Inflammation and Tissue Injury. Antioxid. Redox Signal. 2014, 20 (7), 1126-1167.

(35) Hitchon, C. a; El-Gabalawy, H. S. Oxidation in Rheumatoid Arthritis. Arthritis Res. Ther. 2004, 6, 265-278.

(36) Wittmann, C.; Chockley, P.; Singh, S. K.; Pase, L.; Lieschke, G. J.; Grabher, C. Hydrogen Peroxide in Inflammation: Messenger, Guide, and Assassin. Adv. Hematol. 2012, vol. 2012 (Article ID 541471), 6 pages.

(37) Gutowski, M.; Kowalczyk, S. A Study of Free Radical Chemistry: Their Role and Pathophysiological Significance. Acta Biochim. Pol. 2013, 60 (1), 1-16.

(38) Wruck, C. J.; Fragoulis, A.; Gurzynski, A.; Brandenburg, L.-O.; Kan, Y. W.; Chan, K.; Hassenpflug, J.; Freitag-Wolf, S.; Varoga, D.; Lippross, S.; Pufe, T. Role of Oxidative Stress in Rheumatoid Arthritis: Insights from the Nrf2-Knockout Mice. Ann. Rheum. Dis. 2011, 70 (5), 844-850.

(39) Weinstain, R.; Savariar, E. N.; Felsen, C. N.; Tsien, R. Y. In Vivo Targeting of Hydrogen Peroxide by Activatable Cell- Penetrating Peptides. J. Am. Chem. Soc. 2014, 136, 874-877.

(40) Mueller, S. Sensitive and Nonenzymatic Measurement of Hydrogen Peroxide in Biological Systems. Free Radic. Biol. Med. 2000, 29 (5), 410-415.

(41) Boveris, A.; Alvarez, S.; Bustamante, J.; Valdez, L. Measurement of Superoxide Radical and Hydrogen Peroxide Production in Isolated Cells and Subcellular Organelles. Methods Enzymol. 2002, 349, 280-287.

(42) Stones, J. R.; Yang, S. Hydrogen Peroxide: A Signalling Messenger. Antioxid. Redox Signal. 2006, 8 (3-4), 243-270. 
(43) Kumar, R.; Han, J.; Lim, H. J.; Ren, W. X.; Lim, J. Y.; Kim, J. H.; Kim, J. S. Mitochondrial Induced and Self-Monitored Intrinsic Apoptosis by Antitumor Theranostic Prodrug: In Vivo Imaging and Precise Cancer Treatment. J. Am. Chem. Soc. 2014, 136 (51), 17836-17843.

(44) Perez, C.; Monserrat, J.-P.; Chen, Y.; Cohen, S. M. Exploring Hydrogen Peroxide Responsive Thiazolidinone-Based Prodrugs. Chem. Commun. 2015, 51 (33), 7116-7119.

(45) Peng, X.; Gandhi, V. ROS-Activated Anticancer Prodrugs: A New Strategy for TumorSpecific Damage. Ther. Deliv. 2012, 3 (7), 823-833.

(46) Hagen, H.; Marzenell, P.; Jentzsch, E.; Wenz, F.; Veldwijk, M. R.; Mokhir, A. Aminoferrocene-Based Prodrugs Activated by Reactive Oxygen Species. J. Med. Chem. 2012, 55, 924-934.

(47) Kuang, Y.; Balakrishnan, K.; Gandhi, V.; Peng, X. Hydrogen Peroxide Inducible DNA Cross-Linking Agents: Targeted Anticancer Prodrugs. J. Am. Chem. Soc. 2011.

(48) Chen, W.; Balakrishnan, K.; Kuang, Y.; Han, Y.; Fu, M.; Gandhi, V.; Peng, X. Reactive Oxygen Species (ROS) Inducible DNA Cross-Linking Agents and Their Effect on Cancer Cells and Normal Lymphocytes. J. Med. Chem. 2014, 57 (11), 4498-4510.

(49) Daniel, K. B.; Major Jourden, J. L.; Negoescu, K. E.; Cohen, S. M. Activation of Sulfonate Ester Based Matrix Metalloproteinase Proinhibitors by Hydrogen Peroxide. J. Biol. Inorg. Chem. 2011, 16 (2), 313-323.

(50) Vadukoot, A. K.; Abdulsalam, S. F.; Wunderlich, M.; Pullen, E. D.; Landero-Figueroa, J.; Mulloy, J. C.; Merino, E. J. Design of a Hydrogen Peroxide-Activatable Agent That Specifically Targets Cancer Cells. Bioorganic Med. Chem. 2014, 22 (24), 6885-6892.

(51) Hanna, R. D.; Naro, Y.; Deiters, A.; Floreancig, P. E. Alcohol, Aldehyde, and Ketone Liberation and Intracellular Cargo Release through Peroxide-Mediated-Boryl Ether 
Fragmentation. J. Am. Chem. Soc. 2016, 138, 2016.

(52) Kralovec, J.; Spencer, G.; Blair, A. H.; Mammen, M.; Singh, M.; Ghose, T. Synthesis of Methotrexate-Antibody Conjugates by Regiospecific Coupling and Assessment of Drug and Antitumor Activities. J. Med. Chem. 1989, 32 (11), 2426-2431.

(53) Rosowsky, A.; Bader, H.; Freisheim, J. H. Analogues of Methotrexate and Aminopterin with (Gamma)-Methylene and (Gamma)-Cyano Substitution of the Glutamate Side Chain: Synthesis and in Vitro Biological Activity. J. Med. Chem. 1991, 34 (1), 203-208.

(54) Tao, H.; Peralta-Yahya, P.; Lin, H.; Cornish, V. W. Optimized Design and Synthesis of Chemical Dimerizer Substrates for Detection of Glycosynthase Activity via Chemical Complementation. Bioorganic Med. Chem. 2006, 14 (20), 6940-6953.

(55) Magnus, P.; Gallagher, T. Studies on the Synthesis of the Antitumour Agent CC-1065. Synthesis of the Cyclopropapyrroloindole Portion. J. Chem. Soc. Chem. Commun. 1984, 0, 389-390.

(56) Adlercreutz, P. Immobilisation and Application of Lipases in Organic Media. Chem. Soc. Rev. 2013, 42 (15), 6406.

(57) Montgomery, J. A.; Piper, J. R.; Elliott, R. D.; Temple, C.; Roberts, E. C.; Shealy, Y. F. Analogs of Methotrexate. J. Med. Chem. 1979, 22 (7), 862-868.

(58) Choi, E.-M. Oxidative Status of DBA/1J Mice with Type II Collagen-Induced Arthritis. J. Appl. Toxicol. 2007, 27 (5), 472-481.

(59) Wang, X.; Zhong, W. Isorhamnetin Attenuates Collagen-Induced Arthritis via Modulating Cytokines and Oxidative Stress in Mice. Int. J. Clin. Exp. Med. 2015, 8 (9), 16536-16542.

(60) Sahu, D.; Sharma, S.; Singla, R. K.; Panda, A. K. Antioxidant Activity and Protective Effect of Suramin against Oxidative Stress in Collagen Induced Arthritis. Eur. J. Pharm. Sci. 2017, 
101, 125-139.

(61) National Cancer Institute. Cell Miner. NCI-60 panel of methotrexate and aminopterin https://discover.nci.nih.gov/cellminer/. Accessed on August 11, 2017.

(62) Jones, T. J. M. and D. C. The Metabolism and Toxicity of Quinones, Quinonimines, Quinone Methides, and Quinone-Thioethers. Curr. Drug Metab. 2002, 3 (4) 425-438.

(63) Dou, Y.; Chen, Y.; Zhang, X.; Xu, X.; Chen, Y.; Guo, J.; Zhang, D.; Wang, R.; Li, X.; Zhang, J. Non-Proinflammatory and Responsive Nanoplatforms for Targeted Treatment of Atherosclerosis. Biomaterials 2017, 143, 93-108.

(64) Gottlieb, H. E.; Kotlyar, V.; Nudelman, A. NMR Chemical Shifts of Common Laboratory Solvents as Trace Impurities. J. Org. Chem. 1997, 62 (21), 7512-7515.

(65) Chung, S. H.; Lin, T. J.; Hu, Q. Y.; Tsai, C. H.; Pan, P. S. Synthesis of Boron-Containing Primary Amines. Molecules 2013, 18 (10), 12346-12367.

(66) Mosey, R. A.; Floreancig, P. E. Versatile Approach to $\alpha$-Alkoxy Carbamate Synthesis and Stimulus-Responsive Alcohol Release. Org. Biomol. Chem. 2012, 10 (39), 7980-7985.

(67) Elliott, R. D.; Temple, C.; Montgomery, J. A. Potential Folic Acid Antagonists. IV. Synthetic Approaches to Analogs of Aminopterin and Methotrexate. IV. Preparation of P\{[(2,4-Diamino-6-Pteridinyl)methyl]amino\}benzoic Acids. J. Org. Chem. 1970, 35 (5), 1676-1680.

(68) Zidar, N.; Tomašić, T.; Šink, R.; Rupnik, V.; Kovač, A.; Turk, S.; Patin, D.; Blanot, D.; Contreras Martel, C.; Dessen, A.; Müller Premru, M.; Zega, A.; Gobec, S.; Peterlin Mašič, L.; Kikelj, D. Discovery of Novel 5-Benzylidenerhodanine and 5-Benzylidenethiazolidine2,4-Dione Inhibitors of MurD Ligase. J. Med. Chem. 2010, 53 (18), 6584-6594.

(69) Malavašič, Č.; Grošelj, U.; Golobič, A.; Bezenšek, J.; Stanovnik, B.; Stare, K.; Wagger, J.; 
Svete, J. Synthesis and Structure of Novel (S)-1,6-Dialkylpiperazine-2,5-Diones and (3S,6S)-1,3,6-Trialkylpiperazine-2,5-Diones. Tetrahedron: Asymmetry 2011, 22 (6), 629640.

(70) Barclay, T. G.; Constantopoulos, K.; Zhang, W.; Fujiki, M.; Petrovsky, N.; Matisons, J. G. Chiral Self-Assembly of Designed Amphiphiles: Influences on Aggregate Morphology. Langmuir 2013, 29 (32), 10001-10010.

(71) Riebeseel, K.; Biedermann, E.; Löser, R.; Breiter, N.; Hanselmann, R.; Mülhaupt, R.; Unger, C.; Kratz, F. Polyethylene Glycol Conjugates of Methotrexate Varying in Their Molecular Weight from MW 750 to MW 40000: Synthesis, Characterization, and Structure-Activity Relationships in Vitro and in Vivo. Bioconjug. Chem. 2002, 13 (4), 773785.

(72) Fu, S.-C. J. Para-[N-Bis-(2-Chloroethyl)]-Aminobenzoylglutamic Acid. J. Med. Pharm. Chem. 1962, 5 (1), 33-41.

(73) Vernall, A. J.; Stoddart, L. A.; Briddon, S. J.; Hill, S. J.; Kellam, B. Highly Potent and Selective Fluorescent Antagonists of the Human Adenosine A3 Receptor Based on the 1,2,4-Triazolo[4,3-A]quinoxalin-1-One Scaffold. J. Med. Chem. 2012, 55 (4), 1771-1782.

(74) Lellouche, J. P.; Naddaka, M.; Peled, A.; Mondal, E. Surface-Modified Polymer Films. U.S. Patent 20110306722 A1, December 15, 2011.

(75) Patil, S.; Lis, L. G.; Schumacher, R. J.; Norris, B. J.; Morgan, M. L.; Cuellar, R. A. D.; Blazar, B. R.; Suryanarayanan, R.; Gurvich, V. J.; Georg, G. I. Phosphonooxymethyl Prodrug of Triptolide: Synthesis, Physicochemical Characterization, and Efficacy in Human Colon Adenocarcinoma and Ovarian Cancer Xenografts. J. Med. Chem. 2015, 58 (23), 9334-9344. 


\section{TABLE OF CONTENT GRAPHICS}

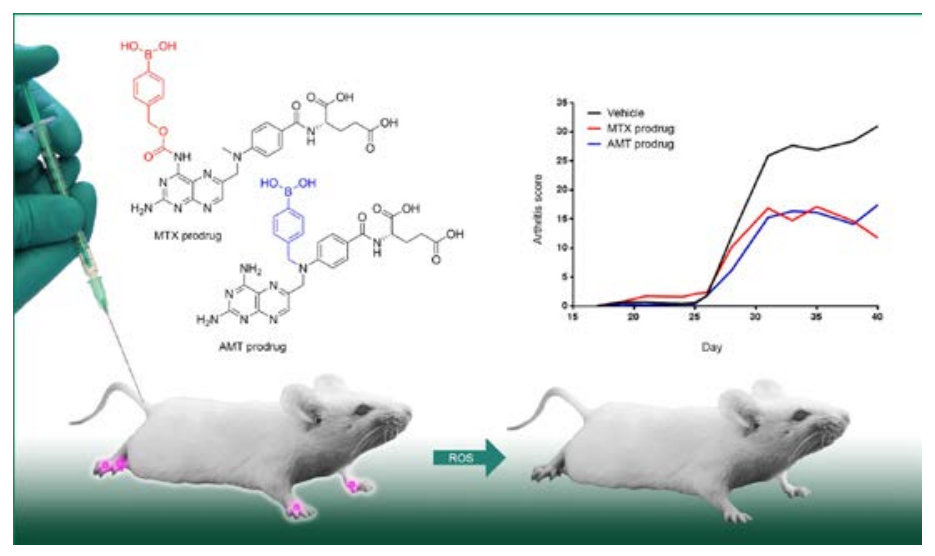

